\title{
Default, Credit Growth, and Asset Prices
}

\author{
Miguel A. Segoviano Basurto, \\ Charles Goodhart, and Boris Hofmann
}




\title{
IMF Working Paper
}

\author{
Monetary and Financial Systems Department \\ Default, Credit Growth, and Asset Prices
}

\section{Prepared by Miguel A. Segoviano Basurto, Charles Goodhart, and Boris Hofmann'}

\author{
Authorized for distribution by S. Kal Wajid
}

September 2006

\begin{abstract}

\section{This Working Paper should not be reported as representing the views of the IMF.} The views expressed in this Working Paper are those of the author(s) and do not necessarily represent those of the IMF or IMF policy. Working Papers describe research in progress by the author(s) and are published to elicit comments and to further debate.
\end{abstract}

This paper uses a Merton-type estimate of the probability of default (PoD) for the main banks in a sample of Organization for Economic Cooperation and Development and middle-income countries as a proxy for the fragility of their banking systems. Based on theory and stylized facts, the paper explores a range of financial and real variables that explain such PoDs across time. We find property price fluctuations and bank credit to be important explanatory factors. There is two-way interaction between these variables and a clearer relationship when the variables are entered as a deviation from trend. The lag structure between such developments and PoDs is long and varies widely across countries. The paper assesses the implications of these findings for economic policy.

JEL Classification Numbers:C14, C22, C50, C61, C82, E32, E37, E44, E51

Keywords: Probability of default, credit risk, systemic risk, macroeconomic shocks, stress testing, financial surveillance

Authors E-Mail Addresses: msegoviano@imf.org; caegoodhart@aol.com; boris.hofmann@ecb.int

\footnotetext{
${ }^{1}$ Charles Goodhart is a Professor Emiritus of Banking and Finance at the London School of Economics (tel. +44207-955-7555), Miguel Angel Segoviano Basurto is an economist at the International Monetary Fund (+1-202-6236260), Boris Hofmann is an economist at the European Central Bank.
} 
I. Introduction 3

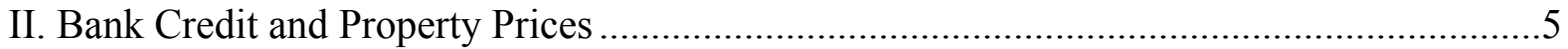

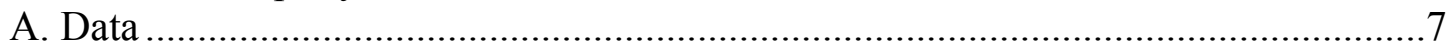

III. Default, Credit Growth, and Asset Prices .................................................................. 14

A. The Dependent Variable ................................................................................... 14

B. The Initial Set of Explanatory Variables ........................................................... 15

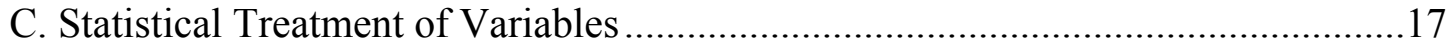

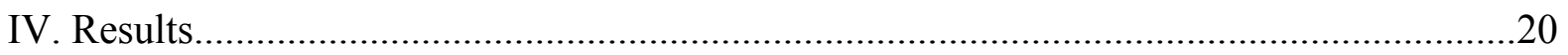

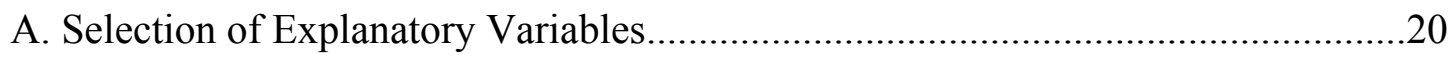

B. Lag Structure of Explanatory Variables........................................................25

C. Robust Estimators: Conditional Probability of Default Methodology ....................27

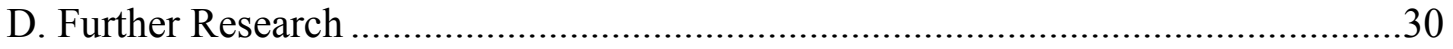

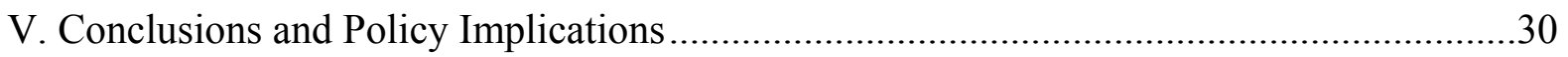

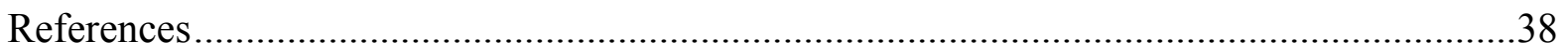

Tables

1. Summary of Impulse Response Analysis .......................................................

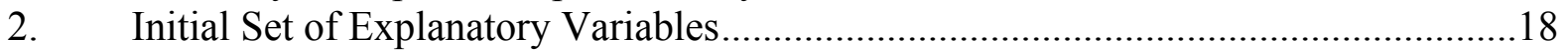

3. Dynamic Hodrick-Prescott Filtering............................................................ 19

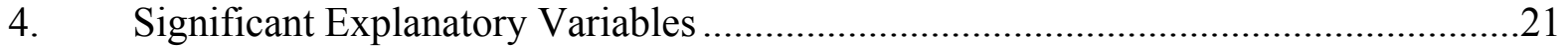

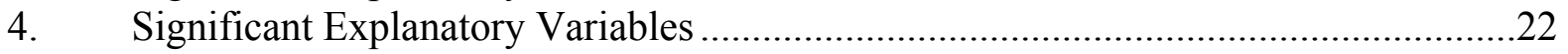

5a. Summary Results_Common Significant Variables ..............................................23

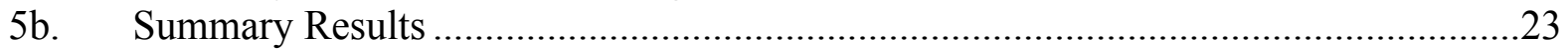

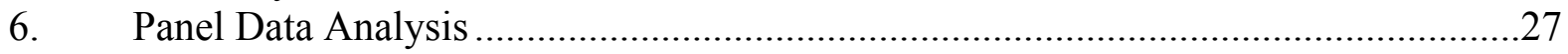

7. Conditional Probability of Default Estimators ................................................28

Figures

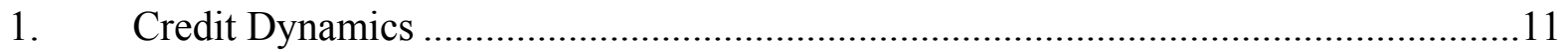

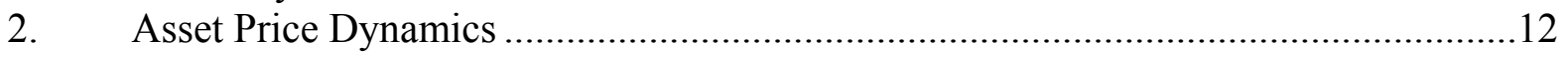

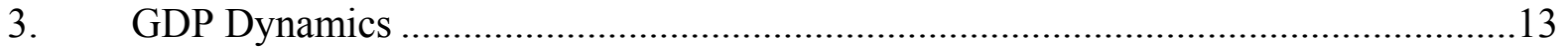

A1. Dynamic Interaction Between Credit and Asset Prices ..........................................32

Appendices

1. Impulse Responses of Credit to Asset Prices Shocks and Asset Prices to Credit........32

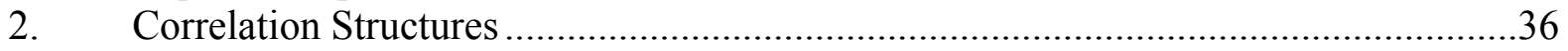




\section{INTRODUCTION}

The analytical relationships between financial markets for defaultible financial assets and the real economy remain obscure. This is, perhaps, because the maintained assumption in most macroeconomic theoretical models is that all agents always pay their debts (with probability one). This then implies that all agents can borrow (lend) an indefinite amount (to maximize their intertemporal utility) at the risk-free rate. So, there is consequently no need for financial intermediaries, and only one market (for the risk-free asset) where in such models the interest rate is, in most cases, set by the reaction function of a central bank, interacting with the expectations of the private sector. Woodford (2003) is the canonical example. In this, there are no commercial banks (or any other intermediary), no default, and only one financial market.

Attempts are being made to bring default back into mainstream macroeconomic theory, as it should be. Shubik and several of his followers have made a start with developing markets in which the probability of default takes a central position. ${ }^{2}$ Goodhart, Sunirand, and Tsomocos (2004a, 2005, and 2006) have been trying to extend and develop the Shubik-type models with the aim of modeling financial fragility in a theoretically rigorous, but empirically tractable form. Kiyotaki and Moore (1997) have also been developing models in which the commitment to repay debt is less than 100 percent. $^{3}$

This paucity of theoretical structure has meant that most work in the field of the interaction between financial fragility and real developments - apart from the transmission mechanism via the risk-less real interest rate- has been via empirically-driven studies. This paper is in this latter tradition.

Although some proponents of real business-cycle theories argue that real factors, e.g., technological advances, are vastly more important than financial factors, it is hard to look at recent developments - Japan since 1985, the Scandinavian boom/bust of the early 1990s, the East Asian crisis of 1997-98, the dot.com bubble, and the widespread housing price cycles in evidence today - without believing in the importance of primarily financial factors. Apart, perhaps, from the years 1939-70, when financial freedom was widely repressed, the same has been true historically.

How, then, should one approach an empirical study of the interaction between financial developments and the real economy? No doubt there are many possibilities. One common starting point has been event studies, notably the event of a financial crisis. This has been very fruitful, notably in many World Bank studies (Demirgüc-Kunt and Detriagiache, 1998, 1999. See also Kaminsky and Reinhart, 1999, and Demirgüc-Kunt and Detriagiache, 2005, for a recent survey).

\footnotetext{
${ }^{2}$ See Shubik (1973 and 1999), Shapley, and Shubik (1977), Shubik and Tsomocos (1992), and Shubik and Wilson (1997).

${ }^{3}$ See their Clarendon lectures on "Evil is the Root of All Money" (2001).
} 
But this approach, inevitably, has certain drawbacks. The exact timing, duration, and intensity of a crisis are all measured with uncertainty. Often crises may be averted by preventative prior action. Is there, therefore, any bias resulting from the study of cases where crises were not averted, while no attention has been paid when crises were averted? Study of a particular crisis on its own runs the risk of putting aside the evidence from noncrisis years.

Perhaps the main innovation in this paper is that we replace crises events as the main dependent variable with a Merton-type estimate of the probability of default (PoD) of the main banks in each of our sample of countries. As with any empirical approach, this has several deficiencies. In particular, the resultant series, in our view, appear to be too sensitive to factors that affect the aggregate level and variance of the equity market rather than the particular robustness or fragility of the banking system. Thus the decline and enhanced volatility of the overall national stock markets, after the collapse of the dot.com bubble in the early 2000s, suggest with regard to this measure a degree of fragility among national banking systems that we doubt was really there in many cases (e.g., the United Kingdom, Spain, and the Netherlands). For such reasons, we feel that sectoral and company-level estimates of PoDs need to be further enhanced in order to distinguish nationwide, sectoral, and idiosyncratic influences - some form of decomposition, which has yet to be done.

Primarily, any empirical exercise runs into the difficulty that there are a legion of factors that might influence the variable under consideration - in this case, the PoD of the main banks in each country. How does one limit the range of variables and all their transforms? Inevitably one leans on a combination of theory, stylized facts from the prior literature, and one's own earlier works.

Our own earlier work, notably Goodhart, Hofmann, and Segoviano (2004), Goodhart and Segoviano (2004), and Segoviano and Lowe (2002), has indicated the close relationship between asset price fluctuations in the property market (residential and commercial), bank lending to the private sector, and the real economy. Based on our evidence, the property market is a far more important driver of both banking robustness and, partly via the banking system, of the economy than are equity markets, or even - in a surprisingly large number of cases - the foreign exchange market (Goodhart and Hofmann, 2001 and 2005).

Of course, the interactions between bank credit extension and the property market are twoway. Most prior studies have only considered unidimensional effects. Section II presents some new cross-country and panel evidence of the two-way interaction between the property market, bank lending to the private sector, and the real economy.

The institution that has done much of the work on the interaction between asset prices, bank lending, and the real economy has been the Bank for International Settlements (BIS), notably in the papers by Borio, Kennedy, and Prowse (1994) and Borio and Lowe (2002). What they have typically found is that surges in the ratio of bank lending to GDP are a common indicator of subsequent financial crises. Again, booms in asset prices generally-so long as property prices are given due weight - tend to be followed by busts that impinge on the banking system and the real economy. 
In prior work, we have independently analyzed these statistical relationships (Segoviano, 2005). There we confirmed that these two variables did commonly affect banking sector PoDs and that the relationship was clearer when the variables were entered as a deviation from trend, than in first difference form. Thus, building on this prior work, we reexamine in Sections III and IV the effects of these two main financial variables on banking sector PoDs for a much wider range of countries. One of the problems here is that, not only is the lag structure between such developments and banking sector PoDs quite long (which may be a boon for the authorities' prudential management), but also the lags seem to vary quite widely from country to country. This is discussed further in Section IV, where the results are presented. The data are described in Section III.

Besides specifically financial developments, bank PoDs are, obviously affected by fluctuations in the real economy. Borrowers fail to repay their debts to the banks (e.g., nonperforming loans) in bad times, and asset prices fall. Thus, banks tend to do worse, and have higher PoDs in cyclical downturns. Consequently, in addition to the financial variables, an assortment of real variables needs to be examined as potential indicators of financial fragility in the shape of bank PoDs.

Given that prior work has suggested a range of leading candidates as variables affecting bank PoDs, we begin by examining the lag structure of their bilateral (correlation) relationship in each country to allow us, among other things, to see whether we might be able to identify a common lag structure, and thereby run a cross-country time series panel exercise, rather than just doing a time series regression for each country separately.

The results in Section IV extend and support earlier work that these two financial variablesthe deviation of bank lending and asset prices - from their trend relationship with GDP, have been able to improve the prediction of bank PoDs. Section V assesses the implications of this for economic policy and future research.

\section{Bank Credit And Property Prices}

The coincidence of cycles in credit and property markets have been widely documented and discussed in the policy oriented literature (IMF, 2000; and BIS, 2001). However, the question of the direction of causality between bank lending and property prices has remained a rather unexplored issue. From a theoretical point of view, causality may go in both directions. Property prices may affect bank lending via various wealth effects. First, due to financial market imperfections, households and firms may be borrowing constrained. As a result, households and firms can only borrow when they offer collateral, so that their borrowing capacity is a function of their collateralizable net worth. ${ }^{4}$ Since property is commonly used as collateral, property prices are therefore an important determinant of the private sector's borrowing capacity. Second, a change in property prices may have a significant effect on

\footnotetext{
${ }^{4}$ Basic references of this literature are Bernanke and Gertler (1989) and Kiyotaki and Moore (1997). For a survey see Bernanke, Gertler, and Gilchrist (1998). An early reference is Fisher (1933).
} 
consumers' perceived lifetime wealth, ${ }^{5}$ inducing them to change their spending and borrowing plans and thus their credit demand in order to smooth consumption over the life cycle. ${ }^{6}$ Finally, property prices affect the value of bank capital, both directly to the extent that banks own assets decrease, and indirectly by affecting the value of loans secured by property. ${ }^{7}$ Property prices therefore influence the risk-taking capacity of banks and thus their willingness to extend loans.

On the other hand, bank lending may affect property prices via various liquidity effects. The price of property can be seen as an asset price, which is determined by the discounted future stream of property returns. An increase in the availability of credit may lower interest rates and stimulate current and future expected economic activity. As a result, property prices may rise because of higher expected returns on property and a lower discount factor. Property can also be seen as a durable good in temporarily fixed supply. An increase in the availability of credit may increase the demand for housing if households are borrowing constrained. With supply temporarily fixed because of the time it takes to construct new housing units, this increase in demand will be reflected in higher property prices.

This potential two-way causality between bank lending and property prices may give rise to mutually reinforcing cycles in credit and property markets. ${ }^{8}$ A rise in property prices, caused by more optimistic expectations about future economic prospects, raises the borrowing capacity of firms and households by increasing the value of collateral. Part of the additional available credit may also be used to purchase property, pushing up property prices even further, so that a self-reinforcing process may evolve.

Little empirical research has been done on the relationship between credit and asset prices. Most studies rely on a single equation set up, focusing either on bank lending or property prices. Goodhart (1995) finds that property prices significantly affect credit growth in the United Kingdom but not in the United States. Hilbers, Lei, and Zacho (2001) find that the change in residential property prices significantly enters multivariate probit-logit models of financial crisis in industrialized and developing countries. Borio and Lowe (2002) show that a measure of the aggregate asset price $^{9}$ gap, measured as the deviation of aggregate asset

\footnotetext{
${ }^{5}$ Data on the composition of household wealth, reported in OECD (2000), show that households hold a large share of their wealth in property.

${ }^{6}$ The lifecycle model of household consumption was originally developed by Ando and Modigliani (1963). A formal exposition of the lifecycle model can be found in Deaton (1992) and Muellbauer (1994).

${ }^{7}$ Chen (2001) develops an extension of the Kiyotaki and Moore (1997) model where an additional amplification of business cycles results from the effect of asset price movements on banks' balance sheets. An early reference for this argument is Keynes (1931).

${ }^{8}$ The possibility of mutually reinforcing cycles in credit and asset markets has already been stressed by Kindleberger (1978) and Minsky (1982).

${ }^{9}$ Aggregate asset price indices are calculated as a weighted average of residential property, commercial property, and equity prices. The weights are based on the share of each asset in national balance-sheets, which are derived based on national flow-of-funds data or UN standardized national accounts. The index weight of
} 
prices from their long-run trend, combined with a similarly defined credit gap measure, is a useful indicator of financial distress in industrialized countries.

Borio, Kennedy, and Prowse (1994) investigate the relationship between credit to GDP ratios and aggregate asset prices for a large sample of industrialized countries over the period 1970-92 using annual data. They focus on the determinants of aggregate asset price fluctuations, hypothesising that the development of credit conditions as measured by the credit to GDP ratio can help to explain the evolution of aggregate asset prices. They find that adding the credit to GDP ratio to an asset pricing equation helps to improve the fit of this equation in most countries. Based on simulations, they demonstrate that the boom-bust cycle in asset markets of the late 1980s and early 1990s would have been much less pronounced or would not have occurred had credit ratios remained constant. For a panel of four East Asian economies (Hong Kong, Korea, Singapore, and Thailand), Collyns and Senhadji (2001) find that credit growth has a significant contemporaneous effect on residential property prices. Based on this finding, they conclude that bank lending has contributed significantly to the real estate bubble in Asia prior to the 1997 East Asian crisis.

All these studies potentially suffer from simultaneity problems because the potential two-way relationship between credit and property prices is not controlled for. In two recent studies, Hofmann (2001) and Gerlach and Peng (2002) analyze the relationship between bank lending and property prices based on a multivariate empirical framework. Hofmann (2001) finds that for a set of 16 industrialized countries, including property prices in the empirical model is imperative for the explanation of the long-run development of bank lending and that long-run causality goes from property prices and real activity to bank lending. Based on impulse response analysis Hofmann (2001) finds that property price innovations have a significant positive effect on bank lending and vice versa, suggesting a two-way relationship between credit and property prices. The problem with this paper's analysis is that the identified patterns of causality are not likely to be invariant to the identifying assumptions imposed upon the estimated VARs. Gerlach and Peng (2002) overcome this problem by analyzing the direction of causality between bank lending and property prices in Hong Kong based on standard regression techniques, controlling for potential simultaneity problems. They find that long-run and short-run causality goes from property prices to lending, rather than conversely.

\section{A. Data}

In the following section we analyze the relationship between real aggregate bank lending, real GDP as a measure of aggregate economic activity, real residential property prices, and real money market interest rates in 18 industrialized countries: Australia, Belgium, Canada, Denmark, Finland, France, Germany, Ireland, Italy, Japan, the Netherlands, New Zealand, Norway, Spain, Switzerland, Sweden, and the United Kingdom, the United States. The data for the industrialized countries were taken from the IMF International Statistics and the 
OECD Economic Outlook database. Residential property prices and an aggregate asset price index, which is calculated as a weighted average of equity prices and residential and commercial property prices, were obtained from the BIS. All data except for the nominal interest rate are seasonally adjusted.

Bank lending, which was transformed into real terms by deflation with the GDP deflator, is defined as total credit to the private nonbank sector. It should be noted that cross-country comparisons of the development of bank lending are flawed by differences in the definition of total credit across countries. These differences in definition will be reflected in the results of the empirical analysis. Differences exist, for example, with respect to the treatment of nonperforming loans in national credit aggregates. A drop in property prices will on one hand has a negative effect on the extension of new loans. On the other hand, it will give rise to an increase in NPLs. The estimated effect of property prices on bank lending will therefore depend on whether banks are forced to write off NPLs quickly or not. For instance, Japan and the Nordic countries experienced severe banking crises in the late 1980s and early 1990s, respectively, which were preceded by a collapse in property prices. ${ }^{10}$ While NPLs were quite quickly cleansed from banks' balance sheets in the Nordic countries, this was not the case in Japan. ${ }^{11}$

Quarterly residential property price indices were available for all countries except Italy, Germany, and Japan. For Japan and Italy, semiannual indices were transformed to quarterly frequency by linear interpolation. For Germany, a quarterly series was generated by linear interpolation of annual data. In order to obtain a measure of real property prices, nominal property prices were deflated with the GDP deflator. We also consider an aggregate asset price index from the BIS in the empirical analysis, as our measure of bank credit comprises bank lending to both households and enterprises, so that residential property prices alone may not fully capture the property price developments which are relevant for aggregate bank lending.

The short-term real interest rate is measured as the three month interbank money market rate less four quarter CPI inflation. The short-term real money market rate serves as a proxy for real aggregate financing costs. A more accurate measure would be an aggregate lending rate. Representative lending rates are, however, not available for most countries. Empirical evidence suggests that lending rates are tied to money market rates at least in the long run, ${ }^{12}$ so that money market rates may serve as a crude approximation of financing costs.

\footnotetext{
${ }^{10}$ Drees and Pazarbasioglu (1998) provide a survey on the causes and consequences of the banking crises in the Nordic countries. The literature on the Japanese crisis is of course enormous. See Hoshi and Kashyap (1999) for a recent survey and the references therein.

${ }^{11}$ For a more detailed discussion of this issue see BIS (2001).

${ }^{12}$ See Borio and Fritz (1995) for a large sample of industrialized countries; Hofmann (2002) for euro area countries; and Hofmann and Mizen (2002 and 2003) for the United Kingdom.
} 
In the following exercise we use a multivariate modelling approach in order to analyze the relationship between bank lending and house and aggregate asset prices based on the VAR model:

$$
x_{t}=A_{1} x_{t-1}+\ldots . .+A_{n} x_{t-n}+\mu+\delta t+\varepsilon_{t} .
$$

Where $x$ is a vector containing the log of the real GDP, the log of real domestic credit to the private sector, the log of real residential property or house prices each multiplied by 100 , and the short-term ex post real interest rate. $t$ is a deterministic time trend. The lag order $n$ was in each case determined by consulting sequential likelihood ratio tests and information criteria (Akaike, Schwarz-Bayes, Hanna-Quinnn, and FPE). We do not perform an explicit analysis of any potential long-run relationships because of the relatively short sample period and large number of endogenous variables. By doing the analysis in levels we allow, however, for implicit cointegrating relationships in the data.

In order to avoid imposing any untested and questionable restrictions, which may bias the results in favor or against finding causality in one or another direction, we adopt a fully astructural approach and simulate one unit shocks to the reduced form residuals of the VAR. As our focus is on the dynamic interaction of credit and asset prices we report in Appendix 1Figure 1 impulse responses of credit to asset price shocks and of asset prices to credit shocks in a two standard error confidence band. It should be recalled that the VARs were estimated separately, once including the aggregate asset price index from the BIS (Model 1) and once including a residential property or house price index (Model 2). Our prior considerations suggest that an increase in property or aggregate asset prices should lead to a significant increase in bank credit and that an increase in bank credit might in turn lead to a significant increase in aggregate asset and property prices. The results of the impulse response analysis are summarized in Table 1, where we respectively report the number of positive responses and the number of significantly positive impulse responses of each variable. The findings suggest that there is significant positive two-way causality between aggregate asset and property prices and credit. However, only in slightly more than half of the countries do we find the effect of house price or aggregate asset price shocks on bank lending to be statistically significant. On the other hand, in slightly less than half of the countries we also find a significantly positive effect of credit shocks on house prices and aggregate asset prices.

Table 1. Summary of Impulse Response Analysis

\begin{tabular}{llclc}
\hline & \multicolumn{2}{l}{ Model 1 (Aggregate Asset Prices) } & \multicolumn{2}{l}{ Model 2 (House Prices) } \\
& Asset Prices & Bank Credit & House Prices & Bank Credit \\
& $\downarrow$ & $\downarrow$ & $\downarrow$ & $\downarrow$ \\
& Bank Credit & Asset Prices & Bank Credit & House Prices \\
\hline Positive responses & 17 & 15 & 14 & 13 \\
Significant responses & 10 & 8 & 11 & 7 \\
\hline
\end{tabular}

Source: Authors' calculations.

This relatively low number of statistically significant impulse responses might be due to the low power of the significance test as a result of the rather short sample period in combination with the sometimes rather long lag lengths that were chosen based on the lag selection tests. 
As a tentative attempt to increase the power of the analysis we exploit the rather large crosssection dimension of our country sample and repeat the impulse response analysis based on a fixed-effects panel VAR estimated over the same sample period. The panel VAR was also estimated separately, once including the aggregate asset price index (Model 1) and once including the house price index (Model 2). In both cases the lag order was again selected by consulting likelihood ratio tests and various information criteria, which in most cases suggested a lag order of 12 , consistent with the long lag orders that were chosen in the individual country VARs.

Figures 1, 2, and 3 report impulse responses from the panel VARs in two standard error bands. Besides the dynamic interaction between bank credit and asset prices we also investigate the dynamic effects of GDP and the real interest rate on bank credit and asset prices as well as the dynamic effects of increases in asset prices, bank credit and real interest rates on real GDP. Again we do not venture to impose any restrictions on the contemporaneous interaction of the variables and rather simulate nonfactorized one unit shocks of the residuals of the reduced form VAR equations. On the whole, the results confirm the findings from the individual country VARs of a significant two-way relationship between credit and asset prices. Bank credit significantly increases after both an increase in aggregate asset prices and in residential property prices (see Figure 1), while both asset price variables show significantly positive responses to an increase in bank credit (see Figure 2). The impulse responses also reveal that an increase in real GDP has a strong and significant positive effect on bank credit (see Figure 1) and asset prices (see Figure 2). Real GDP, in turn, displays a significantly positive response to increases in bank credit and asset prices, suggesting that there might even be a mutually reinforcing relationship involving bank credit, asset prices, and also economic activity. Finally, the impulse responses suggest that an increase in real interest rates leads to a significant decline in bank credit, asset prices and real GDP. 


\section{Figure 1. Credit Dynamics}

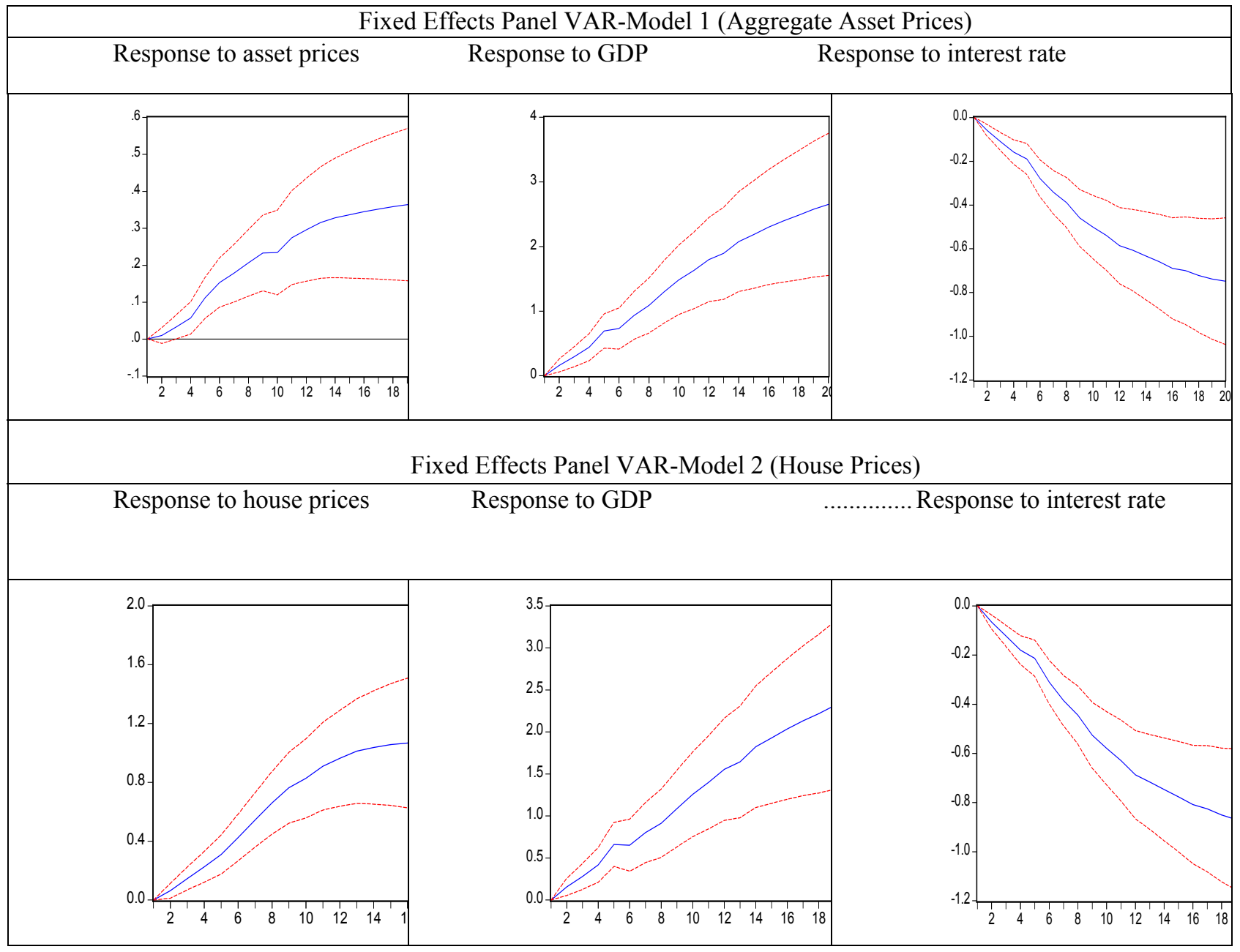

Source: Authors' calculations.

Note: The figures display impulse responses to a one non-factorized one unit shock in a two standard error confidence band. 
Figure 2. Asset Price Dynamics

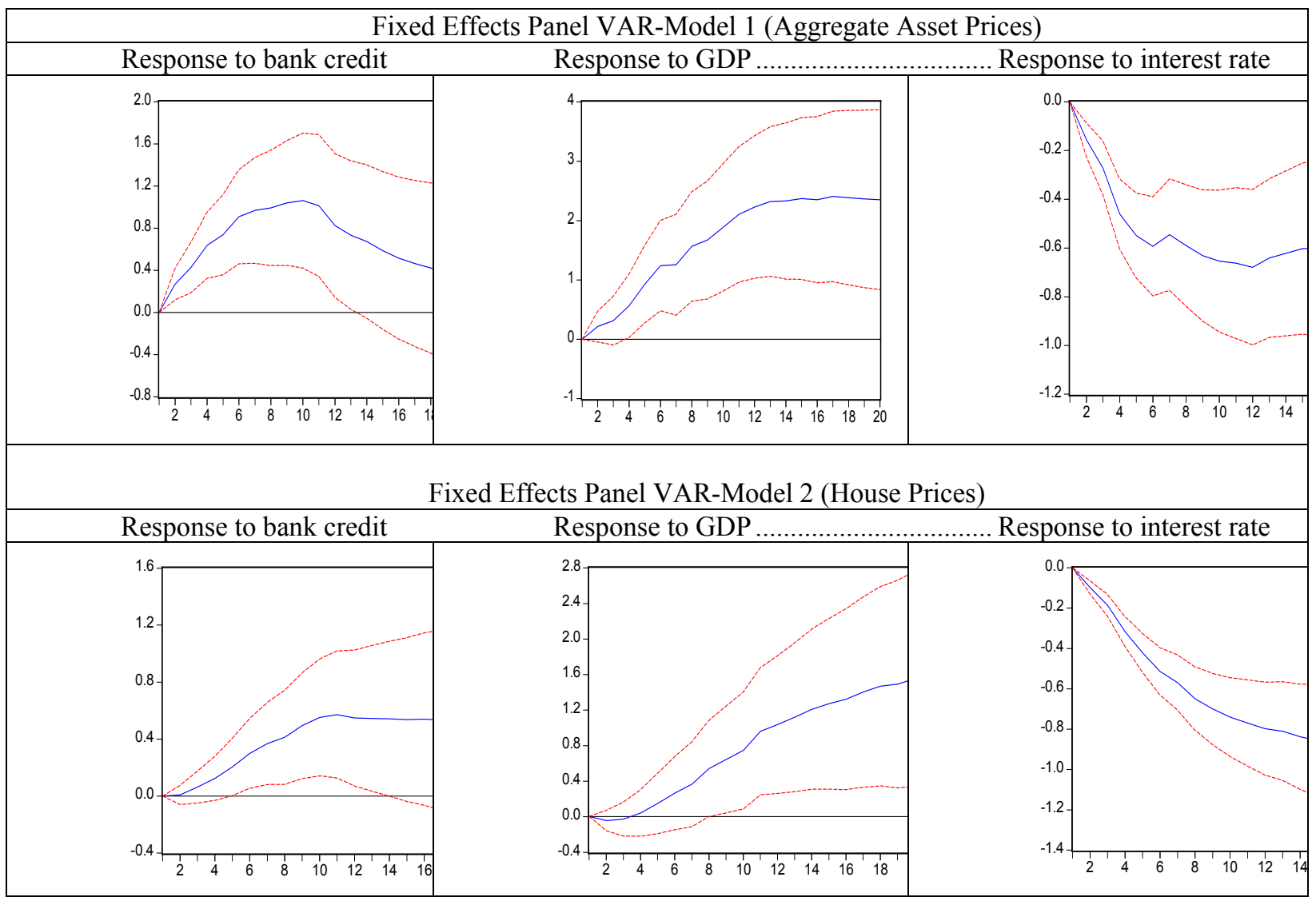

Source: Authors' calculations.

Note: The figures display impulse responses to a one nonfactorized one unit shock in a two standard error confidence band. 
Figure 3. GDP Dynamics

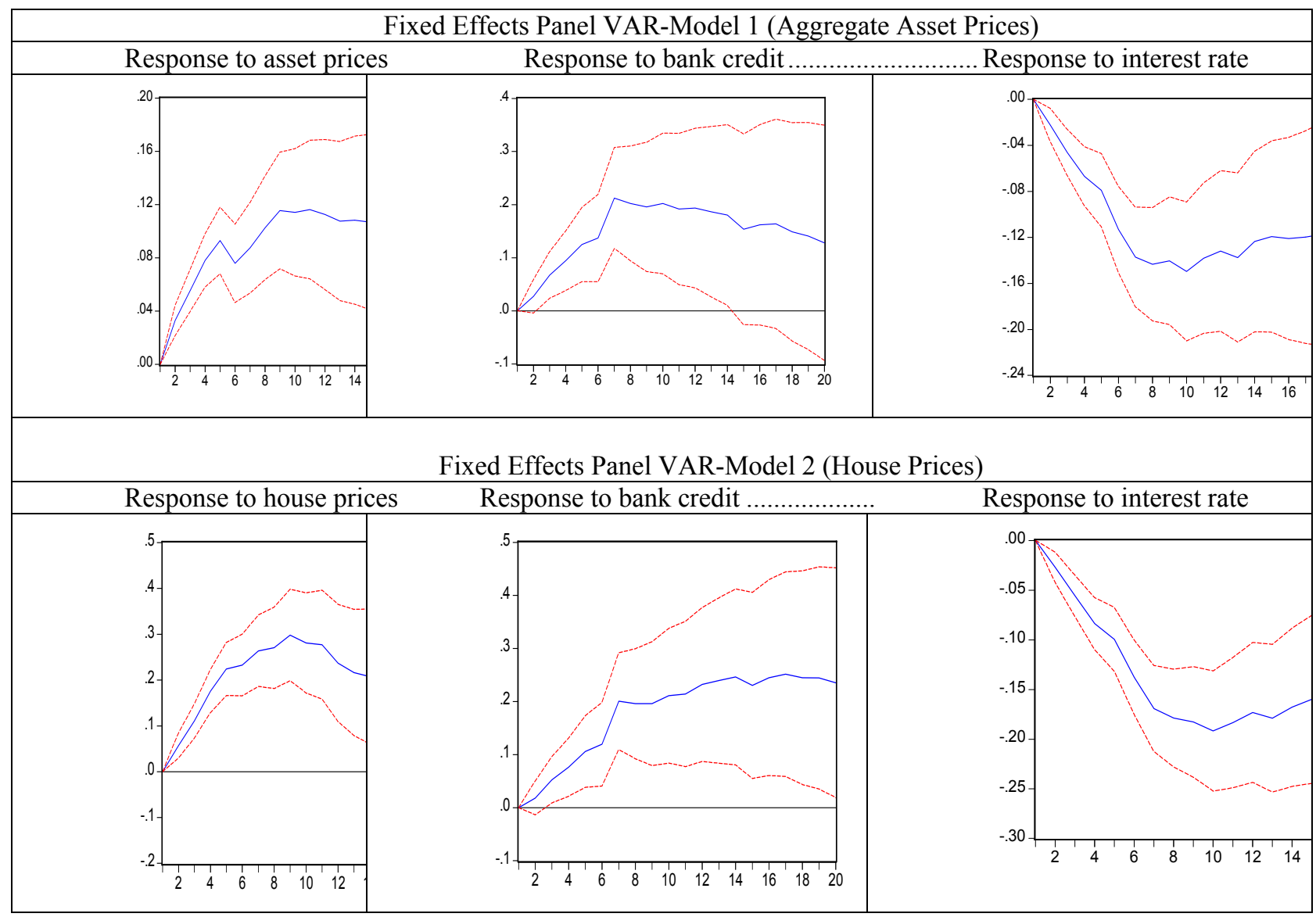

Source: Authors' calculations.

Note: The figures display impulse responses to a one nonfactorized one unit shock in a two standard error confidence band. 


\section{Default, Credit Growth, And Asset Prices}

In this section we analyze the interaction between default, credit growth and asset prices in 17 developed and developing countries: Argentina, Canada, Denmark, Finland, France, Germany, Italy, Japan, Korea, Mexico, Netherlands, Norway, Spain, Sweden, Thailand, UK and the US. The data were taken from the IMF International Statistics and the OECD Economic Outlook database. The aggregate asset price index, which is calculated as a weighted average of equity prices and residential and commercial property prices, were obtained from the BIS. All data except for the nominal interest rate are seasonally adjusted.

\section{A. The Dependent Variable}

The dependent variable that is used in this study is a transformation of the distance-to-default (DD) indicator, which is prepared by the Monetary and Financial Systems Department, Financial Surveillance Policy Division in the IMF.

The DD indicator is used to gauge banking sector soundness. The variables used to calculate the DD indicator are obtained from information contained in bank equity prices and balance sheets of some of the largest financial institutions for each country under analysis.

In a standard valuation model, the DD indicator is determined by (i) the market value of a firm's assets, $V_{A}$; (ii) the uncertainty or volatility of the asset value (risk), $\sigma_{A}$; and (iii) the degree of leverage or the extent of the firm's contractual liabilities, measured as the book value of liabilities at time t, $D_{t}$ (with maturity $T$ ).

The DD indicator is computed as the sum of the ratio of the estimated current value of assets to debt and the return on the market value of assets, divided by the volatility of assets. The formula is given by:

$$
D D_{t}=\frac{\ln \left(V_{A, t} / D_{t}\right)+\left(\mu-\frac{1}{2} \sigma_{A}^{2}\right) T}{\sigma_{A} \sqrt{T}}
$$

Where $\mu$ measures the mean growth of $V_{A}$.

Using market data of equity and annual accounting data, the market value $V_{A}$ and the volatility of assets $\sigma_{A}$ are typically estimated using Black and Scholes (1973) and Merton (1974) options pricing model.

Once the DD is computed, the theoretical probability of default $(\mathrm{PoD})$ is obtained as:

$$
P o D_{t}=N\left(-D D_{t}\right)
$$

Where $N$ is the cumulative probability distribution function $(c d f)$ for a variable that is normally distributed with a mean zero and a standard deviation of 1 (Vassalou and Xing, 2002). 
The theoretical probabilities of default $\left(\mathrm{PoD}_{\mathrm{t}}\right)$ at each period $t$, are grouped in the Tdimensional vector PoD. Since each observation in the vector PoD is restricted to lie between 0 and 1 , we make the following transformation:

$$
Y=N^{-1}(P o D)+5
$$

where $N^{1}$ is the inverse standard normal $c d f .{ }^{13}$ We are interested on modeling the PoD as a function of identifiable macroeconomic and financial developments $X$. We formalize the relationship as:

$$
Y=X B+e
$$

An alternative way to look at this issue is to assume that defaults reflect an underlying, continuous credit change indicator ("normal equivalent deviate" in the language of probit analysis) that has a standard normal distribution. Thus, we can state the relationship as: $P o D=N(X B+e)$, where the inverse normal $c d f$ transformation converts this equation to a linear problem $Y=X B+e$.

\section{B. The Initial Set of Explanatory Variables}

We selected an initial set of explanatory macroeconomic and financial variables that, according to theory and empirical evidence, are likely to affect banks' credit risk. In order to explore the explanatory variables' information content, we computed their fluctuations with respect to a long-term trend, which we denominate "gaps". With the obtained gaps, we ran multivariate ordinary least squares (OLS) regressions to identify the specifications that are consistent with economic theory and empirical evidence and that show the best goodness of fit.

Among the theoretical arguments that can be used as a basis to select the initial set of explanatory variables, we find theoretical models with credit constraints and a financial accelerator (Kiyotaki and Moore, 1997). The relevant economic theory also includes secondgeneration models in the currency crisis literature, which stress the role of self-fulfilling expectations and herding behavior in determining the intensity of the cycles; models that note that under current financially liberalized systems, the scope for risk-taking is increased; and theories that call attention to the creation of perverse mechanisms, such as moral hazard lending and carry trades, that can exacerbate banking and currency crises. ${ }^{14}$

There is a growing empirical literature emphasizing the information content of certain variables. For example, it has been observed that financial liberalization often precedes banking crises. So, variables associated with financial liberalization merit scrutiny. Real

\footnotetext{
${ }^{13}$ In Appendix 2, figures A2a and A2b, we present graphs of the time series of the PoD's and their transformations for a sample of countries.

${ }^{14}$ See Obstfeld (1995), Calvo (1998), and Flood and Marion (1999) for the first. See Allen and Gale (1998) for the second, and Garber and Lall (1996) and Dooley (1997) for the third.
} 
aggregate credit in the economy, the ratio of credit to GDP, M2 balances, real interest rates, and the ratio of M2 to foreign exchange reserves were considered. Pill and Pradhan (1995), Kaminsky and Reinhart (1999), Eichengreen and Areta (2000), and Borio and Lowe (2002) have reported that real aggregate credit in the economy and the ratio of credit to GDP are important indicators of banking problems. McKinnon and Pill (1996) have reported rapid increases in monetary aggregates linked to banking crises. Galbis (1993) reports that real interest rates have increased after financial liberalization. The ratio of M2 to foreign exchange reserves may capture the extent to which the liabilities of the banking system are backed by international reserves. In the event of a currency crisis, individuals may rush to convert their domestic currency deposits into foreign currency, so this ratio could capture the ability of the central bank to meet those demands (Calvo and Mendoza, 1996). Currency crises may take place after a period of large inflows of foreign short-term capital. Such inflows, usually driven by the combined effect of capital account liberalization and high domestic interest rates, result in an expansion of domestic credit (Khamis, 1996). When foreign interest rates rise, domestic ones fall, or when confidence in the economy shifts, foreign investors quickly withdraw their funds and the domestic banking system may become illiquid (Calvo, Leiderman, and Reinhart, 1993).

We included the current account balance since this variable indicates the amount of foreign investment needed in the economy and is therefore a variable that could signal the vulnerability of the economy to shifts in investor confidence. Consumption and investment were also included since these variables can indicate the uses of funding in the economy and therefore can shape the expectations of investors in terms of the capacity of the economy to produce growth opportunities in the future. Foreign Direct Investment was also included as a measure of the vulnerability of the economy to foreign capital. (Sturm, Berger, and Haan 2004). ${ }^{15}$

To capture adverse macroeconomic shocks that hurt banks by increasing the share of NPLs, we considered changes in real GDP. An index of equity and residential property prices and an aggregate asset price index ${ }^{16}$ were also included and justified by the findings of Borio and Lowe (2002) and Goodhart, Hofmann, and Segoviano (2004). ${ }^{17}$

The realized volatility of short-term interest rates was also considered since this variable can affect banks' balance sheets adversely, if they fail to hedge or predict the change. Volatile

\footnotetext{
${ }^{15}$ Sturm, Berger, and Haan (2004) find that the ratio of investment to GDP is robustly related to the probability that a country receives IMF credit. A low ratio of investment to GDP may indicate limited access to international capital markets. Knight and Santaella (1997) and Vreeland (1999) also provide support for this view.

${ }^{16}$ The aggregate asset price index combines prices of three asset classes, equity, residential property, and commercial property. It weights the components by estimates of the shares of the asset classes in private sector wealth. The methodology is described in detailed in Borio, Kennedy, and Prowse (1994). We thank Borio for providing us with the aggregate asset price index series.

${ }^{17}$ Note that, as already mentioned, an alternative explanation of the causes and effects of increases in asset prices is provided by the literature on the agency problem of excessive risk-taking associated with limited liability. See Allen and Gale (1999).
} 
rates and uncertainty affect cash-flow planning and high lending rates result in a larger fraction of NPLs (Mishkin, 1997). ${ }^{18}$ The difference between long and short nominal rates was included as a variable that could indicate market expectations on growth.

Another case of rate of return mismatch occurs when banks borrow in a foreign currency and lend in a domestic currency. In this case, an unexpected depreciation of the domestic currency threatens bank profitability and eventually solvency. Banks that raise funds abroad might choose to issue domestic loans denominated in foreign currency, thus eliminating currency mismatches. In this case, foreign exchange risk is shifted on to borrowers, and an unexpected depreciation would still affect bank profitability negatively through an increase in NPLs. We have therefore included the nominal foreign exchange rate. Foreign currency loans were a source of banking problems in the Nordic countries in the early 1990s (Drees and Pazarbasioglu, 1998) and in Mexico (Mishkin, 1997). A real foreign exchange rate index was also included. ${ }^{19}$

Table 2 provides a summary of the variables that were analyzed, the codes used to identify them, and their source. ${ }^{20}$

\section{Statistical Treatment of Variables}

Our aim in this exercise is to analyze combinations of fluctuations in different macroeconomic and financial variables as possible causes of increases in financial risk. When we compute fluctuations in these variables, they are calculated using only information that would have been available to the analyst up to the time when the analysis was carried out.

These fluctuations are computed with respect to a long-term trend. When computing movements with respect to a long-term trend, we are interested in capturing the explanatory power of cumulative processes, rather than growth rates over just one period. The reasoning behind this approach is that vulnerabilities may build up over an extended period rather than in a single period. We refer to these movements with respect to long-term trends as "gaps."

In order to estimate the long-term trend, we use a "dynamic" Hodrick-Prescott (HP) filter using information from 1970. This procedure is illustrated in Table 3.

\footnotetext{
${ }^{18}$ See also the Global Financial Stability Report, IMF, September 2003 for empirical evidence between financial market volatility and financial system instability.

${ }^{19}$ An increase in the real exchange rate index implies depreciation.

${ }^{20}$ This is not an exhaustive list of potential variables. In particular, political variables can also be linked to financial stability. Variables capturing the effectiveness of the legal system have also been found to be significant in explaining banking sector problems. Variables reflecting exogenous events can also explain specific crises. None of these are considered. For the effect of political variables see Mishra (1997). For the effect of legal structures see Arkelof and Romer (1993).
} 
Table 2. Initial Set of Explanatory Variables

\begin{tabular}{|c|c|c|}
\hline Code & Variable & Source \\
\hline REPROPRI & Residential property prices & $\begin{array}{l}\text { National sources as per detailed documentation and } \\
\text { BIS calculations based on national data. }\end{array}$ \\
\hline SHAPRI & Share price index & IMF International Financial Statistics \\
\hline AGGASPRI & Aggregate asset rrice index & $\begin{array}{l}\text { National sources as per detailed documentation and } \\
\text { BIS calculations based on national data. }\end{array}$ \\
\hline NEER & Nominal FX & IMF International Financial Statistics \\
\hline M2 & M2 monetary aggregate & IMF International Financial Statistics \\
\hline REER & Real FX & IMF International Financial Statistics \\
\hline RESER & International reserves & IMF International Financial Statistics \\
\hline REINT & Real interest rates & IMF International Financial Statistics \\
\hline SHINT & Short interest rates & IMF International Financial Statistics \\
\hline LINT & Long interest rates & IMF International Financial Statistics \\
\hline MTG & Mortgage Bond Interest Rates & National sources \\
\hline REGDP & Real GDP & IMF International Financial Statistics and OECD \\
\hline RECRE & Real aggregate credit & IMF International Financial Statistics and OECD \\
\hline $\mathrm{CON}$ & Consumption aggregate & IMF International Financial Statistics \\
\hline CA & Current account balance & IMF International Financial Statistics \\
\hline FDI & Foreign direct investment & IMF International Financial Statistics \\
\hline REINVE & Investment aggregate & IMF International Financial Statistics \\
\hline RECON & Real consumption & Authors calculations based on national data. \\
\hline CREOVGDP & $\begin{array}{l}\text { Ratio of aggregate credit in the } \\
\text { financial system to GDP }\end{array}$ & Authors calculations based on national data. \\
\hline INVOVGDP & Ratio of investment to GDP & Authors calculations based on national data \\
\hline CONOVGDP & Ratio of consumption to GDP & Authors calculations based on national data \\
\hline RECUAOVREINV & $\begin{array}{l}\text { Ratio of real current account to } \\
\text { real investment }\end{array}$ & Authors calculations based on national data \\
\hline M2OVRES & $\begin{array}{l}\text { Ratio of M2 to international } \\
\text { reserves }\end{array}$ & Authors calculations based on national data \\
\hline LOMISH & $\begin{array}{l}\text { Difference of long minus short } \\
\text { interest rates }\end{array}$ & Authors calculations based on national data \\
\hline INREVO & $\begin{array}{l}\text { Realized volatility of money } \\
\text { market rates }\end{array}$ & Authors calculations based on national data \\
\hline
\end{tabular}

Source: Authors' calculations. 
Table 3. Dynamic Hodrick-Prescott Filtering

\begin{tabular}{lll}
\hline Period & Contemporaneous & Lag 1 (-1) \\
\hline $\mathrm{t}_{1}$ & Gap variable $_{1}=$ variable $_{1}-\mathrm{HTDvariable}_{1}{ }^{1}$ & Gap variable $(-1)_{1}=$ variable $_{0}-\mathrm{HTDvariable}_{0}{ }^{1}$ \\
$\mathrm{t}_{2}$ & Gap variable $_{2}=$ variable $_{2}-\mathrm{HTDvariable}_{2}{ }^{2}$ & Gap variable $(-1)_{2}=$ variable $_{1}-\mathrm{HTDvariable}_{1}{ }^{2}$ \\
$\mathrm{t}_{3}$ & Gap variable $_{3}=$ variable $_{3}-\mathrm{HTDvariable}_{3}{ }^{3}$ & Gap variable $(-1)_{3}=$ variable $_{2}-\mathrm{HTDvariable}_{2}{ }^{3}$ \\
$\mathrm{t}_{4}$ & Gap variable $_{4}=$ variable $_{4}-\mathrm{HTDvariable}_{4}{ }^{4}$ & Gap variable $(-1)_{4}=$ variable $_{3}-\mathrm{HTDvariable}_{3}{ }^{4}$ \\
$\mathrm{t}_{5}$ & Gap variable $_{5}=$ variable $_{5}-\mathrm{HTDvariable}_{5}{ }^{5}$ & Gap variable $(-1)_{5}=$ variable $_{4}-\mathrm{HTDvariable}_{4}{ }^{3}$ \\
\hline
\end{tabular}

Source: Authors' calculations.

Where, HTD is the HP trend component.

Subscripts refer to the time of the observation.

Superscripts refer to the information set included.

For example, let us assume that we were currently at $t_{3}$ and we wanted to estimate the gap for a given variable at time $t_{3}$ (contemporaneous gap). First, using a HP filter, we would include information from 1970 up until $t_{3}$ to compute the trend component (superscript in the HP trend component, e.g., HTDvariable ${ }^{3}$ ). Second, we would obtain the difference between the value of the variable at $t_{3}$ (subscript in the variable component. e.g., variable ${ }_{3}$ ) and the value of the trend component at $t_{3}$ (subscript in the trend component e.g., HTDvariable H $_{3}$; therefore:

$$
\text { GapVariable }_{3}=\text { Variable }_{3}-\text { HTDVariable }_{3}{ }^{3}
$$

Note that we only use information up to the period that we analyze, e.g., $t_{3}$, because at $t_{3}$ an analyst would only have information up to this date.

In order to estimate lags for the gaps we followed a similar procedure. If we were at $t_{3}$ and we wanted to estimate the credit gap lagged one period, using an HP filter, we would first include information from 1970 up until $t_{3}$ to compute the trend component (superscript in the HP trend component, e.g., HTDvariable ${ }^{3}$ ). However, in the second step, we would obtain the difference between the value of the variable at $t_{2}$ (lagged one period, e.g., subscript in the variable component, e.g., variable ${ }_{2}$ ) and the value of the trend component at $t_{2}$ (lagged one period, e.g., subscript in the trend component, e.g., HTDvariable 2 ); therefore:

$$
\text { GapVariable }(-1)_{3}=\text { Variable }_{2}-\mathrm{HTDV}_{\text {ariable }}{ }^{3} \text {. }
$$

This procedure was repeated for all the included lags.

Note that we do not consider the long-term trend from which the gaps are defined as "fundamental values." This distinction highlights a key issue, especially in the case of price variables, since we do not try to identify asset price bubbles. An asset price bubble can be characterized by a significant over-pricing of an asset from its "fundamental value." There is no attempt in this paper to assess "fundamental values" and measure price deviations from them. For the purposes of this exercise, the more relevant issue is to assess the combination 
of events that has the potential to increase banks' credit risk. Consequently, we do not enter the market efficiency debate.

\section{Results}

\section{A. Selection of Explanatory Variables}

Using the model defined in equation 6, we run multivariate OLS regressions, exploring different combinations of variables "gaps" with different lags. For all the countries under analysis, we used up to 28 lags since the frequency of the data was quarterly. ${ }^{21}$

Since the time series of the dependent variables contain few observations, we tried to be as parsimonious as possible. ${ }^{22}$ As a result, we started specifying regression systems with the fewest possible variables and explored how far these could take us. We continued increasing the set of explanatory variables used in the specifications, keeping in mind the trade-off with degrees of freedom when increasing regressors. Therefore, we restricted specifications to contain two, three, and five explanatory variables for each country under analysis.

Once we defined the number of explanatory variables to be included in each specification, we computed OLS multivariate regressions for all the possible combinations with the defined number of explanatory variables for each specification.

Model specifications were selected based on the consistency of the explanatory variables with theoretical arguments and empirical evidence and on the specifications' goodness of fit, indicated by the adjusted R-squared and akaike criteria. Under these criteria, Table 4 shows the best specifications with five explanatory variables for Japan, Mexico, Thailand, and the United States. We chose to show full results for Japan and the United States because they are large economies in different geographical areas. Mexico and Thailand were chosen since they represent developing countries that have experienced financial crises and are located in different geographical areas. Tables $5 \mathrm{a}$ and $5 \mathrm{~b}$ show summary results of all the countries under analysis. Full results of any of the analyzed countries are available upon request.

\footnotetext{
${ }^{21}$ We assumed that longer lags were not consistent with economic theory.

${ }^{22}$ The number of observations for different countries varied from 40 to 57 .
} 
Table 4. Significant Explanatory Variables

Results for Japan

\begin{tabular}{lllll}
\hline \multicolumn{4}{l}{ Ordinary Least Squares for Japan } \\
\hline Variables & Coefficient & p-value & Std. Error & Variance \\
\hline C & 0.3219 & 0.11 & 0.4902 & 0.2403 \\
GapCREDOVGDP(-12) & 57.8900 & 0.00 & 13.8316 & 191.3134 \\
GapAGGPRINDX(-3) & 40.1377 & 0.00 & 5.7478 & 33.0371 \\
GapRECON & -67.0655 & 0.00 & 20.8029 & 432.7594 \\
GapREINVE(-19) & -21.0558 & 0.00 & 5.0515 & 25.5181 \\
LOMISH(-3) & 1.2118 & 0.00 & 0.3889 & 0.1512 \\
R-squared & 0.6020 & Schwarz criterion & 3.3541 \\
Adjusted R-squared & 0.5614 & F-statistic & 14.8227 \\
Akaike info. criterion & 3.1351 & Prob(F-statistic) & 0.0000 \\
\hline
\end{tabular}

Dependent Variable: YJAP. Method: OLS. Sample: 1990: Q4-2004: Q2. Included observations: 55.

Newey-West HAC standard errors and covariance (lag truncation=2).

\section{Results for the United States}

\begin{tabular}{lllll}
\hline \multicolumn{5}{l}{ Ordinary Least Squares for the United States } \\
\hline Variables & Coefficient & p-value & Std. Error & Variance \\
\hline C & -1.6170 & 0.00 & 0.2374 & 0.0563 \\
GapCREOVGDP(-9) & 108.0178 & 0.00 & 20.8465 & 434.5753 \\
GapAGGAPRI(-5) & 23.3065 & 0.00 & 4.4208 & 19.5433 \\
GapM2OVRES(-7) & 9.5320 & 0.00 & 1.9578 & 3.8330 \\
GapRECRAOVREINV(-5) & 247.4801 & 0.03 & 109.1042 & 11903.7265 \\
GapLINT(-4) & -1.4158 & 0.00 & 0.4137 & 0.1711 \\
R-squared & 0.6886 & Schwarz criterion & 3.7919 \\
Adjusted R-squared & 0.6581 & F-statistic & & 22.5560 \\
Akaike info criterion & 3.5768 & Prob(F-statistic) & & 0.0000 \\
\hline
\end{tabular}

Dependent Variable: YUS Method: OLS Sample: 1990Q4-2004Q4. Included observations: 57 Newey-West HAC Standard Errors \& Covariance (lag truncation=2). 
Table 4. Significant Explanatory Variables (Continued)

Results for Mexico

\begin{tabular}{lllll}
\hline \multicolumn{5}{l}{ Ordinary Least Squares Results for Mexico } \\
\hline Variables & Coefficient & p-value & Std. Error & Variance \\
\hline C & 2.7448 & 0.00 & 0.0516 & 0.0027 \\
GapCREOVGDP(-12) & 2.2882 & 0.00 & 0.2936 & 0.0862 \\
GapAGGAPRI(-20) & 8.1228 & 0.00 & 1.3265 & 1.7597 \\
GapREGDP(-9) & -7.3825 & 0.00 & 0.9727 & 0.9461 \\
GapINVEOVGDP(-17) & -2.0643 & 0.02 & 0.7732 & 0.5979 \\
GapM2OVRES(-5) & 0.4872 & 0.00 & 0.1455 & 0.0212 \\
R-squared & 0.8864 & Schwarz criterion & 0.4983 \\
Adjusted R-squared & 0.8530 & F-statistic & 26.5324 \\
Akaike info criterion & 0.2020 & Prob(F-statistic) & 0.0000 \\
\hline
\end{tabular}

Dependent Variable: YMEX Method: OLS Sample: 1995Q2-2004Q4 Included observations:23.

Newey-West HAC Standard Errors \& Covariance (lag truncation=2).

\section{Results for Thailand}

\begin{tabular}{lllll}
\hline \multicolumn{5}{c}{ Ordinary Least Squares Results for Thailand } \\
\hline Variables & Coefficient & p-value & Std. Error & Variance \\
\hline C & 2.7350 & 0.00 & 0.1724 & 0.0297 \\
GapCREOVGDP(-9) & 15.7708 & 0.00 & 1.8695 & 3.4949 \\
GapAGGASPRI(-11) & 0.8720 & 0.00 & 0.1860 & 0.0346 \\
LOMISH(-1) & -0.2657 & 0.00 & 0.0313 & 0.0010 \\
GapRECUAOVREINV(-5) & 147.5645 & 0.00 & 37.9664 & 1441.4437 \\
GapM2OVRES(-11) & 4.0804 & 0.01 & 1.4538 & 2.1136 \\
R-squared & 0.8171 & Schwarz criterion & 3.1984 \\
Adjusted R-squared & 0.7855 & F-statistic & 25.9046 \\
Akaike info criterion & 2.9318 & Prob(F-statistic) & 0.0000 \\
\hline
\end{tabular}

Source: Authors' calculations.

Dependent Variable:YTHA. Method: OLS. Sample: 1996Q2-2004Q4. Included observations: 35 .

Newey-West HAC Standard Errors \& Covariance (lag truncation=2). 
In order to make our analysis more tractable, we summarize our results in Table 5a and Table $5 b$.

Table 5a. Summary Results—Common Significant Variables

\begin{tabular}{|c|c|c|c|c|c|c|c|c|c|c|c|c|c|c|c|c|c|c|c|}
\hline Variable & $\begin{array}{l}\mathrm{S} \\
\mathrm{I} \\
\mathrm{G} \\
\mathrm{N}\end{array}$ & HOR* & $\begin{array}{l}A \\
R \\
G \\
\end{array}$ & $\begin{array}{l}\mathrm{C} \\
\mathrm{A} \\
\mathrm{N}\end{array}$ & $\begin{array}{l}\mathrm{D} \\
\mathrm{N} \\
\mathrm{K} \\
\end{array}$ & $\begin{array}{l}\mathrm{F} \\
\mathrm{I} \\
\mathrm{N}\end{array}$ & $\begin{array}{l}\mathrm{F} \\
\mathrm{R} \\
\mathrm{A}\end{array}$ & $\begin{array}{l}\mathrm{G} \\
\mathrm{E} \\
\mathrm{R}\end{array}$ & $\begin{array}{l}\mathrm{I} \\
\mathrm{T} \\
\mathrm{A} \\
\end{array}$ & $\begin{array}{l}\mathrm{J} \\
\mathrm{A} \\
\mathrm{P}\end{array}$ & $\begin{array}{l}\mathrm{K} \\
\mathrm{O} \\
\mathrm{R} \\
\end{array}$ & $\begin{array}{l}\mathrm{M} \\
\mathrm{E} \\
\mathrm{X} \\
\end{array}$ & $\begin{array}{l}\mathrm{N} \\
\mathrm{E} \\
\mathrm{T}\end{array}$ & $\begin{array}{l}\mathrm{N} \\
\mathrm{O} \\
\mathrm{R}\end{array}$ & $\begin{array}{l}\mathrm{S} \\
\mathrm{P} \\
\mathrm{A}\end{array}$ & $\begin{array}{l}\text { S } \\
\text { W } \\
\text { E }\end{array}$ & $\begin{array}{l}\mathrm{T} \\
\mathrm{H} \\
\mathrm{A} \\
\end{array}$ & $\begin{array}{l}\mathrm{U} \\
\mathrm{K} \\
\end{array}$ & $\begin{array}{l}\mathrm{U} \\
\mathrm{S}\end{array}$ \\
\hline CREOVGDP & + & ME & 9 & 6 & 7 & 15 & 7 & 17 & 6 & 12 & 25 & 12 & 5 & 17 & 7 & 8 & 9 & 7 & 9 \\
\hline $\begin{array}{l}\text { AGGASPRI } \\
\text { REINVE / }\end{array}$ & + & ME & 12 & 3 & 5 & 19 & $\begin{array}{l}3 \\
2\end{array}$ & 3 & 6 & 3 & 24 & 20 & 12 & 18 & 7 & 4 & 11 & 9 & 5 \\
\hline INVEOVGDP & - & LO & 17 & 7 & 22 & 16 & 1 & 14 & 21 & 19 & 17 & 17 & 15 & 28 & 21 & & & 24 & 26 \\
\hline INREVO & + & $\mathrm{SH}$ & & & & 1 & 5 & 3 & & $6 * *$ & 1 & 3 & & 1 & & 1 & 5 & 6 & \\
\hline LOMISH & - & $\mathrm{SH}$ & 5 & 3 & 4 & & $\begin{array}{l}8 \\
1\end{array}$ & & & $3 * *$ & & & 1 & & 2 & 1 & 1 & 1 & \\
\hline REGDP & - & $\mathrm{SH} / \mathrm{ME}$ & 16 & 11 & 3 & 18 & 1 & 3 & 9 & & 7 & 9 & & 1 & 1 & & & & \\
\hline RECUAOVREINV & + & ME & 21 & 14 & & & & & & & & & & 7 & & & 5 & 8 & 5 \\
\hline NEER / REER & - & SH & 3 & 14 & 3 & 2 & 5 & 0 & 3 & & & & 3 & & & 3 & & & \\
\hline
\end{tabular}

Source: Authors' calculations.

* Horizon: Short (SH), Medium (ME), Long (LO).

** The coefficients of these variables present opposite signs

Table 5b. Summary Results

\begin{tabular}{|c|c|c|c|c|c|c|}
\hline Country & $\begin{array}{l}\text { CREVGDP } \\
\text { p-value }\end{array}$ & Lag & $\begin{array}{l}\text { AGGASPRI } \\
\text { p-value }\end{array}$ & Lag & Other Variables 1/ & $\begin{array}{c}\mathrm{R}- \\
\text { Squared }\end{array}$ \\
\hline Argentina & $\begin{array}{l}5.960511 \\
0.0883\end{array}$ & 9 & $\begin{array}{l}0.941071 \\
0.0003\end{array}$ & 12 & $\begin{array}{l}\text { LOMISH(-5), M2OVRES(-11), REGDP(- } \\
\text { 16), } \\
\text { NEER(-3), RECUAOVREINVE(-21), } \\
\text { REINVE(-17) }\end{array}$ & 0.7266 \\
\hline Canada & $\begin{array}{l}26.283130 \\
0.0721\end{array}$ & 6 & $\begin{array}{l}32.878250 \\
0.0000\end{array}$ & 3 & $\begin{array}{l}\text { REINVE(-7), LINT(-2), REER(-14), } \\
\text { REGDP(-11), } \\
\text { RECUAOVREINV(-14), LOMISH(-3) }\end{array}$ & 0.6003 \\
\hline Denmark & $\begin{array}{l}23.198240 \\
0.0007\end{array}$ & 7 & $\begin{array}{l}23.743620 \\
0.0000\end{array}$ & 5 & $\begin{array}{l}\text { NEER(-3), MTG(-3), LOMISH(-4), } \\
\text { REGDP(-3), REINVE(-22) }\end{array}$ & 0.5770 \\
\hline Finland & $\begin{array}{l}21.273600 \\
0.0015\end{array}$ & 15 & $\begin{array}{l}12.276910 \\
0.0027\end{array}$ & 19 & $\begin{array}{l}\text { INREVO(-1), NEER(-2), REGDP(-18), } \\
\text { INVEOVGDP(-16), LINT(-5) }\end{array}$ & 0.5835 \\
\hline France & $\begin{array}{l}72.775970 \\
0.0000\end{array}$ & 7 & $\begin{array}{l}14.298550 \\
0.0062\end{array}$ & 3 & $\begin{array}{l}\operatorname{INREVO}(-5), \operatorname{REGDP}(-11), \\
\operatorname{INVEOVGDP}(-21) \\
\text { M2OVGDP(-1), NEER(-5), LOMISH(-8) }\end{array}$ & 0.4850 \\
\hline Germany & $\begin{array}{l}34.241200 \\
0.0002\end{array}$ & 17 & $\begin{array}{l}30.433080 \\
0.0004\end{array}$ & 3 & $\begin{array}{l}\text { NEER, REGDP(-3), INREVO(-3), } \\
\text { INVEOVGDP(-14) }\end{array}$ & 0.6456 \\
\hline Italy & $\begin{array}{l}24.709120 \\
0.0001\end{array}$ & 6 & $\begin{array}{l}20.929280 \\
0.0000\end{array}$ & 6 & $\begin{array}{l}\text { REGDP(-9), NEER(-3), INVEOVGDP(-21), } \\
\text { SHINT(-8) }\end{array}$ & 0.6925 \\
\hline Japan & $\begin{array}{l}57.890040 \\
0.0001\end{array}$ & 12 & $\begin{array}{l}40.137660 \\
0.0000\end{array}$ & 3 & $\begin{array}{l}\text { RECON, REINVE(-19), } \\
\text { LOMISH(-3), INREVO(-6) }\end{array}$ & 0.6020 \\
\hline Korea & $\begin{array}{l}21.343080 \\
0.0005\end{array}$ & 25 & $\begin{array}{l}0.849931 \\
0.0032\end{array}$ & 24 & $\begin{array}{l}\text { REGDP(-7), REINVE(-17), MTG(-1), } \\
\operatorname{INREVO(-1),~M2OVRES(12)~}\end{array}$ & 0.6117 \\
\hline
\end{tabular}


Table 5b. Summary Results (concluded)

\begin{tabular}{|c|c|c|c|c|c|c|}
\hline \multirow{2}{*}{ Mexico } & 2.288178 & \multirow{2}{*}{12} & 8.122759 & \multirow{2}{*}{20} & REGDP(-9), INVEOVGDP(-17), & \multirow{2}{*}{0.8864} \\
\hline & 0.0000 & & 0.0000 & & M2OVRES(-5), INREVO(-3) & \\
\hline Netherlands & $\begin{array}{l}79.332200 \\
0.0233\end{array}$ & 5 & $\begin{array}{l}17.169250 \\
0.0273\end{array}$ & 12 & $\begin{array}{l}\text { LOMISH(-1), REER(-3), INVOVGDP(-15), } \\
\text { SINT(-1), INVOVGDP(-15) }\end{array}$ & 0.5864 \\
\hline Norway & $\begin{array}{l}17.786020 \\
0.0603\end{array}$ & 17 & $\begin{array}{l}7.313933 \\
0.0331\end{array}$ & 18 & $\begin{array}{l}\text { INREVO(-1), RECUAOVREINV(-7), } \\
\text { REINVEL28, REGDP(-1) }\end{array}$ & 0.6829 \\
\hline Spain & $\begin{array}{l}84.548890 \\
0.0000\end{array}$ & 7 & $\begin{array}{l}27.004740 \\
0.0000\end{array}$ & 7 & $\begin{array}{l}\text { INVEOVGDP(-21), LOMISH(-2), } \\
\text { REGDP(-1), SINT(-6) }\end{array}$ & 0.8309 \\
\hline Sweden & $\begin{array}{l}20.420020 \\
0.0220\end{array}$ & 8 & $\begin{array}{l}3.943797 \\
0.0939\end{array}$ & 4 & $\begin{array}{l}\text { LOMISH(-1), M2OVRES(-4), } \\
\text { LINT(-3), INREVO(-1), NEER(-3) }\end{array}$ & 0.6659 \\
\hline Thailand & $\begin{array}{l}15.77079 \\
0.0000\end{array}$ & 9 & $\begin{array}{l}0.872030 \\
0.0001\end{array}$ & 11 & $\begin{array}{l}\text { LOMISH(-1), RECUAOVREINV(-5), } \\
\text { INREVO(-5), M2OVRES(-11) }\end{array}$ & 0.8171 \\
\hline $\begin{array}{l}\text { United } \\
\text { Kingdom }\end{array}$ & $\begin{array}{l}24.551260 \\
0.0065\end{array}$ & 7 & $\begin{array}{l}18.178800 \\
0.0002\end{array}$ & 9 & $\begin{array}{l}\text { LOMISH(-1), LINT(-3), } \\
\text { RECUAOVREINV(-8) }\end{array}$ & 0.6962 \\
\hline $\begin{array}{l}\text { United } \\
\text { States }\end{array}$ & $\begin{array}{l}108.017800 \\
0.0000\end{array}$ & 9 & $\begin{array}{l}23.306530 \\
0.0000\end{array}$ & 5 & $\begin{array}{l}\text { M2OVRES(-7), RECUAOVREINV(-5), } \\
\text { LINT(-4), REINVE(-26) }\end{array}$ & 0.6886 \\
\hline
\end{tabular}

Source: Authors' calculations.

1/ All of these variables, except LOMISH and INREVO, were transformed to "gaps" as indicated in section III.C.

Lags are indicated in parenthesis.

From Tables 4, 5a, and 5b, we observe that the variables that significantly explained the dependent variable in all the countries under analysis, were the gap of credit over GDP (CREDOVGDP) and the gap of aggregate asset prices (AGGASPRI). The gap of real investment (REINVE) or investment over GDP (INVOVGDP) also seems to be significant in most cases.

The realized volatility of money market rates (INREVO), the difference of long minus short interest rates (LOMISH), the gap of real GDP (REGDP), the gap of real current account over real investment (RECUAOVREINV), and the gap of nominal foreign exchange (FX) (NEER) or real FX (REER) showed significant explanatory power in many cases, but not in all the countries.

From the results, we see that the signs of the gap of credit over GDP (CREDOVGDP) and the gap of aggregate asset prices (AGGASPRI), are as expected by economic theory and empirical evidence.

Although, intuitively, one might expect that the higher the amount of investment in the economy, the higher the opportunities for growth and therefore, the lower the probabilities of corporate defaults as a result of banking problems, there are nevertheless, few economic theory foundations on which we could support our findings with respect to real investment (REINVE) or investment over GDP (INVOVGDP); e.g., the "long horizon" variables. Consequently, we would suggest care in drawing conclusions about these variables. Although these variables were highly significant in all the countries under analysis, it could be the case that the relationships that were found, may be due to a cyclical phenomenon of the data, given that the period under analysis is relatively short (from 1990 onward). 
We would also wish to be cautious in drawing conclusions with respect to the results observed for the realized volatility of money market rates (INREVO) and the gap of real GDP (REGDP); e.g., the "short horizon" variables. These variables were highly significant for most of the countries under analysis. Note that one would expect that, in environments of high interest rate volatility, both banks' balance sheets and NPLs are affected adversely. Equally, negative GDP performance might increase the share of NPLs . However, the fact that both of these variables appear to be significant at very short lags (although the lags for GDP vary greatly across countries), may be driven by common responses along with the PoDs to a third driving factor (simultaneity in the data). Therefore, although our findings for the "long horizon" and "short horizon" variables are superficially quite appealing, we would like to conduct further research before we can draw conclusions.

\section{B. Lag Structure of Explanatory Variables}

Although the signs of the coefficients of the significant explanatory variables in Tables 5a and $5 \mathrm{~b}$ are generally consistent with economic theory and empirical evidence, ${ }^{23}$ the lag structure of these variables in each country under analysis differs considerably.

As policy makers, we are interested in trying to identify a significant pattern (across countries) in the lag structure of the variables that we have identified as having an effect on banking credit risk. Therefore, we proceeded to compute cross-country panel data estimations. $^{24}$

For this purpose, when we analyzed the information summarized in Tables $5 \mathrm{~b}$ and 6 , we observed that the gap of credit over GDP (CREOVGDP) was significant at lags varying from 5 to 17 quarters.

Equally, the gap of the aggregate asset price index (AGGASPRI) was significant at lags varying between 3 and 24 lags. Finally, the gaps of real investment (REINVE) or investment over GDP (INVOVGDP) were significant at longer horizons, varying between 14 and 28 lags.

From these observations, we decided to analyze the correlation structures of the dependent variable and each of the three most significant variables: e.g., Corr(y,CREOVGDP), Corr(y,AGGASPRI), Corr(y,REINVE/INVOVGDP) at lags t-4, t-8, t-12, t-16, t-20, and t-24 for the first two variables and $\mathrm{t}-4, \mathrm{t}-8, \mathrm{t}-12, \mathrm{t}-24$, and $\mathrm{t}-28$ for the last variable. The correlation matrices are presented in Appendix 2.

\footnotetext{
${ }^{23}$ We mainly focused on the "medium horizon" variables since we require further analysis of the "short horizon" and "long horizon" variables as already argued in Section IV.A.

${ }^{24}$ Note that apart from identifying significant cross-country patterns, usually, when modelers are faced with short time series, panel data analysis is used as a possible route to alleviate the problems related to restricted data sets. However, if pooling restrictions are artificially imposed in the presence of different economic structures, there could be cases when the results of panel data regressions do not show significant variables. The methodology proposed in Section IV.C for robust estimators could also be seen as an alternative route to panel data estimation that could allow us to deal with small sample problems without imposing pooling restrictions.
} 
From the correlation matrices, we observe that the highest correlations between the dependent and each of the analyzed explanatory variables, usually coincide with the lags at which the explanatory variables were significant in the best (reported) specifications.

Furthermore, we see that Corr(y,CREOVGDP) is usually higher at a medium term (e.g., around t-8), Corr(y,AGGASPRI) is also usually higher at a medium-term (e.g., around t-8), although there are some cases in which the lag structure is much longer. We also observe that Corr(y,REINVE/INVOVGDP) is higher at longer horizons (e.g., most frequently at horizons t-12 or longer).

From this prior analysis, we decided to run cross-country panel data regressions, pooling the information for all the countries under analysis, imposing different lag structures (e.g., t-4, $\mathrm{t}-8$, and $\mathrm{t}-12$ ). Results were as follows:

We turned to this panel exercise to see if we could obtain a better estimate of the relative contribution of these two long-term determinants of financial fragility. When we ran three lags of both the credit and asset gap variables (at $\mathrm{t}-4, \mathrm{t}-8, \mathrm{t}-12$ ), either separately or jointly, see Table 6 , the coefficients of both variables at each of these lags remained significant, ${ }^{25}$ (apart from that of the asset price gap, at $\mathrm{t}-8$, in the joint exercise). ${ }^{26} \mathrm{We}$ examined various restricted combinations of lags in the two variables, e.g., combining the credit gap variable at $\mathrm{t}-8$ with the asset price gap variable at $\mathrm{t}-8$, or $\mathrm{t}-12$, or $\mathrm{t}-16$, but the results remained quite flat, i.e., the adjusted $\mathrm{R}^{2}$ values remained almost unchanged, and are not shown here.

As already discussed in Section II, these two main explanatory variables interact closely; causality runs in both directions between them, i.e., there is much simultaneity, and it is reinforcing. It is therefore, difficult to distinguish their individual effects. This latter exercise to try to take further account of their individual and interactive effects, will be for further research.

\footnotetext{
${ }^{25}$ This result differed from that in our earlier exercise using only data from developed countries. In this case the asset price gap variable tended to dominate the credit gap variable in the joint panel exercises where both were included, i.e., only the first set of variables remained significant. This is consistent with a lesser role of capital markets (and of private housing/property) in less developed countries, relative to the role of banks, (than in more developed countries).

${ }^{26}$ When we excluded Thailand from the sample, all the variables seem to be significant.
} 
Table 6. Panel Data Analysis

\begin{tabular}{|c|c|c|c|c|c|c|}
\hline \multirow{2}{*}{$\begin{array}{l}\text { Pooled Results } \\
\text { Variables }\end{array}$} & \multicolumn{2}{|c|}{ CREOVGDP } & \multicolumn{2}{|c|}{ AGGASPRI } & \multicolumn{2}{|c|}{ CREOVGDP, AGGASPRI } \\
\hline & Coefficient & $\mathrm{p}$-value & Coefficient & $\mathrm{p}$-value & Coefficient & $\mathrm{p}$-value \\
\hline $\mathrm{C}$ & -0.222234 & 0.0606 & -0.241499 & 0.0502 & -0.233910 & 0.0462 \\
\hline GapCREOVGDP(-4) & 5.765883 & 0.0017 & & & 6.779743 & 0.0005 \\
\hline GapCREOVGDP(-8) & 5.614949 & 0.0045 & & & 6.989937 & 0.0005 \\
\hline GapCREOVGDP(-12) & 2.142127 & 0.0940 & & & 5.594157 & 0.0000 \\
\hline GapAGGASPRI(-4) & & & 1.321767 & 0.0148 & 3.954792 & 0.0000 \\
\hline GapAGGASPRI(-8) & & & 0.592124 & 0.0835 & 0.631641 & 0.8269 \\
\hline GapAGGASPRI(-12) & & & 1.299631 & 0.0000 & 1.232816 & 0.0000 \\
\hline Pooled Results & \multicolumn{2}{|c|}{ CREOVGDP } & \multicolumn{2}{|c|}{ AGGASPRI } & \multicolumn{2}{|c|}{ CREOVGDP, AGGASPRI } \\
\hline \multicolumn{7}{|l|}{ Fixed Effects (Cross) } \\
\hline Argentina $-\mathrm{C}$ & \multicolumn{2}{|c|}{1.544946} & \multicolumn{2}{|c|}{1.506961} & \multicolumn{2}{|c|}{1.221646} \\
\hline Canada-C & \multicolumn{2}{|c|}{-2.389238} & \multicolumn{2}{|c|}{-2.350746} & \multicolumn{2}{|c|}{-2.376745} \\
\hline Denmark-C & \multicolumn{2}{|c|}{-1.332561} & \multicolumn{2}{|c|}{-1.364117} & \multicolumn{2}{|c|}{-1.313546} \\
\hline Finland-C & \multicolumn{2}{|c|}{0.066321} & \multicolumn{2}{|c|}{0.027537} & \multicolumn{2}{|c|}{0.080117} \\
\hline Franc-C & \multicolumn{2}{|c|}{0.362307} & \multicolumn{2}{|c|}{0.377582} & \multicolumn{2}{|c|}{0.356009} \\
\hline Germany-C & \multicolumn{2}{|c|}{-0.538898} & \multicolumn{2}{|c|}{-0.528559} & \multicolumn{2}{|c|}{-0.544731} \\
\hline Italy-C & \multicolumn{2}{|c|}{0.378045} & \multicolumn{2}{|c|}{0.393455} & \multicolumn{2}{|c|}{0.352232} \\
\hline Japan-C & 1.75 & & 1.7 & & 1.7 & \\
\hline Korea-C & 2.30 & & 2.3 & & 2.4 & \\
\hline Mexico-C & 2.80 & & 2.9 & & 2.7 & \\
\hline Netherlands--C & -1.13 & & -1.1 & & -1.1 & \\
\hline Norway $-\mathrm{C}$ & 0.34 & & 0.2 & & 0.4 & \\
\hline Spain-C & -1.58 & & -1.5 & & -1.5 & \\
\hline Sweden-C & 0.20 & & 0.2 & & 0.1 & \\
\hline Thailand-C & 2.68 & & 2.4 & & 2.5 & \\
\hline United Kingdom--C & -0.73 & & -0.7 & & -0.7 & \\
\hline United States--C & -1.68 & & -1.6 & & -1.6 & \\
\hline R-squared & 0.3 & & & & & \\
\hline Adjusted R-squared & 0.2 & & & & & \\
\hline Akaike info criterion & 4.5 & & & & & \\
\hline Schwarz criterion & 4.6 & & & & & \\
\hline F-statistic & 20. & & & & & \\
\hline Prob(F-statistic) & 0.0 & & & & & \\
\hline
\end{tabular}

Source: Authors' calculations.

Dependent Variable: YPooled. Method: Pooled LS. Sample: 1990Q4-2004Q4.

Included observations: 57 after adjustments. Cross-sections included: 17.

White cross-section standard errors \& covariance (d.f. corrected).

\section{Robust Estimators: Conditional Probability of Default Methodology}

Up to now, our attention has focused on selecting the set of explanatory variables to include in the model. For this purpose, we have used multivariate OLS regressions. However, the time series of the PoDs are short. 
The need to carry out short-time series analysis is commonly faced by credit risk modelers. Under these circumstances, the OLS estimators have large variances and OLS estimators can be sensitive to small changes in the data.

So we intend to extend the analysis presented here by recovering the parameters of the selected explanatory variables with the conditional probability of default (CoPoD) methodology, presented in Segoviano (2006). The CoPoD (based on the Jaynes (1957) entropy measure), recovers estimators that, when dealing with short samples, are superior to OLS estimators under the mean square error (MSE) criterion. Equivalently, the CoPoD greatly reduces the variance of the estimators. This feature should improve the evaluation of the impact of macroeconomic and financial shocks on the credit risk of the financial system.

The CoPoD estimation procedure could be understood as a "nonparametric" maximumlikelihood estimation procedure, in which, rather than finding the estimators by optimizing the parameters of a parametric (given) likelihood function, the likelihood function is inferred from the data observations.

The theoretical and implementation details of the CoPoD are provided in Segoviano (2006). This paper presents theoretical results showing that the CoPoD estimation procedure reduces the variance of the estimators in the presence of small samples (vis-à-vis OLS estimation). The implementation procedure of a Monte Carlo simulation experiment by which it is possible to estimate the variance of the CoPoD and OLS estimators is also presented in this paper. This Monte Carlo experiment endorses the mentioned theoretical results. Table 7 shows the CoPoD estimators of the specifications presented in Table 4.

Table 7. Conditional Probability of Default Estimators

Results for Japan

\begin{tabular}{lccc}
\hline & Conditional Probability of Default for Japan & \\
\hline Variables & Coefficient & Std. Error & Variance \\
\hline C & 0.2970 & 0.2178 & 0.0474 \\
GapCREDOVGDP(-12) & 59.1579 & 8.5210 & 72.6074 \\
GapAGGPRINDX(-3) & 40.5239 & 4.3060 & 18.5420 \\
GapRECON & -67.4923 & 12.1909 & 148.6178 \\
GapREINVE(-19) & -21.3154 & 3.6207 & 13.1097 \\
LOMISH(-3) & 1.2326 & 0.2594 & 0.0673 \\
\hline
\end{tabular}

Dependent Variable: YJAP. Method: OLS. Sample: 1990Q4-2004Q2. Included observations: 55. 
Table 7. Conditional Probability of Default Estimators (concluded).

Results for the United States

\begin{tabular}{lccc}
\hline \multicolumn{4}{c}{ Conditional Probability of Default Results for the United States } \\
\hline Variables & Coefficient & Std. Error & Variance \\
\hline C & -1.6065 & 0.1617 & 0.0262 \\
GapCREOVGDP(-9) & 107.8718 & 11.8899 & 141.3693 \\
GapAGGAPRI(-5) & 23.0910 & 3.4587 & 11.9627 \\
GapM2OVRES(-7) & 9.5762 & 1.3920 & 1.9378 \\
GapRECRAOVREINV(-5) & 250.6765 & 71.8472 & 5162.0258 \\
GapLINT(-4) & -1.4093 & 0.2633 & 0.0693 \\
\hline
\end{tabular}

Dependent Variable: YUS. Method: OLS. Sample: 1990Q4-2004Q4. Included observations: 57.

Results for Mexico

\begin{tabular}{lccc}
\hline \multicolumn{4}{c}{ Conditional Probability of Default Results for Mexico } \\
\hline Variables & Coefficient & Std. Error & Variance \\
\hline C & 2.7489 & 0.0208 & 0.0004 \\
GapCREOVGDP(-12) & 2.4206 & 0.2006 & 0.0402 \\
GapAGGAPRI(-20) & 7.9874 & 1.0008 & 1.0016 \\
GapREGDP(-9) & -7.8711 & 0.6972 & 0.4861 \\
GapINVEOVGDP(-17) & -2.0137 & 0.5337 & 0.2848 \\
GapM2OVRES(-5) & 0.4348 & 0.0928 & 0.0086 \\
\hline
\end{tabular}

Dependent Variable: YMEX. Method: OLS. Sample: 1995Q2-2004Q4. Included observations:23.

Results for Thailand

\begin{tabular}{lccc}
\hline \multicolumn{4}{c}{ Conditional Probability of Default Results for Thailand } \\
\hline Variables & Coefficient & Std. Error & Variance \\
\hline C & 2.7189 & 0.1272 & 0.0162 \\
GapCREOVGDP(-9) & 15.6853 & 1.1035 & 1.2178 \\
GapAGGASPRI(-11) & 0.8913 & 0.1335 & 0.0178 \\
LOMISH(-1) & -0.2614 & 0.0190 & 0.0004 \\
GapRECUAOVREINV(-5) & 147.3987 & 19.5326 & 381.5236 \\
GapM2OVRES(-11) & 4.0710 & 0.9593 & 0.9202 \\
\hline
\end{tabular}

Dependent Variable:YTHA. Method: OLS. Sample: 1996Q2-2004Q4. Included observations: 35.

From these results, it is possible to observe that the CoPoD estimators show the same signs as the OLS estimators; thus, the CoPoD estimators remain consistent with economic theory and empirical evidence. However, the CoPoD estimators show greatly reduced variances. 


\section{Further Research}

The results produced indicate the need for further research in an important area: the interaction between credit and asset prices. As shown in Section II, the causality between asset prices (AGGASPRI) and credit over GDP (CREDOVGDP) goes in both directions and is reinforcing. Although these results show that both variables, CREDOVGDP and AGGASPRI, are significant in explaining banking credit risk, further analysis, along the lines of the study presented in Section II, needs to be conducted in order to take further account of the interaction between these variables.

\section{Conclusions And Policy Implications}

This study has reconfirmed some empirical relationships that are already well-known. First, there is a two-way simultaneous relationship between surges in bank lending and asset prices. This relationship is stronger in the case of real estate-both housing and commercial property - than with equity. The links between bank lending and property are manifold, but differ in strength from country to country.

When such a combined bank lending/property boom occurs, there is an enhanced likelihood of financial fragility occurring some two to three years after the year of the preceding boom (note that the lags in the process are quite long). Again, we would emphasize the relative importance of property, as contrasted with the lesser importance of equity prices in this. Although there are differences between countries in lag length and the strength of the estimated relationships, the commonality of findings is quite impressive, especially since there are aspects of the empirical tests (notably the excessive reliance of the PoD estimate on the overall variance of (national) equity markets), that still need improvement.

What, then, are the public policy implications of this exercise? As noted, we have not considered the causes of bank lending/asset price surges. Usually these arise in conditions of strong economic growth, allied with structural changes in the banking system, (e.g., liberalization) that encourage the banks to target growth and to enter new fields of business. Such phenomena were seen in the United Kingdom (1972-74), Scandinavia (1988-90), and Japan (1988-90) and are not particularly Asian in character. That said, China and India, and perhaps Brazil, are countries whose stage of development puts them at risk of repeating this syndrome.

Assuming that despite all precautions a bank lending/property prices surge develops, during such bubbles existing bank regulations and capital adequacy requirements, for example, are not likely to provide adequate restraint. During such asset booms, NPLs decline and bank profits rise. Capital is not a constraint on bank expansion. This reflects the fact that most financial regulation, notably Basel II, is somewhat procyclical. Consequently, such regulatory measures are of little use in counteracting bubble/bust antecedents of financial fragility.

Is it possible to derive contra-cyclical regulatory measures? The Spanish pre-provisioning approach and the Hong Kong time-varying loan-to-value ratios for mortgages are in this 
genre. Pillar 2 of Basel II enables the supervisory authorities to introduce variations in capital requirements, if they so wish.

One of the problems is that financial intermediation has become a globally competitive industry. Indeed, the need for a level playing field has been one of the primary driving forces behind the Basel regulations. Can any one country introduce countercyclical supervisory adjustments, under Pillar 2 or otherwise, without provoking considerable disintermediation either to banks situated abroad or to non-banks? But, if the perceived need is to strengthen domestic banks against boom/bust financial fragility, is such disintermediation necessarily a bad outcome (even though it will be perceived as such by the domestic banks who will lobby furiously against it)?

Even assuming that policy measures cannot be effectively used to diminish bank lending/property booms to manageable levels, and that that bubble eventually bursts, the lengthy lags in the course of the downwards spiral should give the authorities time to prepare their defenses against resulting financial collapse. Stress and scenario tests come into play here. However, the question is not just whether the banks can survive the first-round effect of property price declines - they usually can. The deeper question is whether banks' own reactions, such as limiting new bank loans, and those of their (inter-bank and foreign) depositors, such as withdrawing funding, will lead to second-round effects and subsequent responses that could give a vicious twist to the deflationary spiral. Stress and scenario tests tend to cover only first-round effects. To analyze the resulting possible equilibria, there is a need for general equilibrium models in this area, ${ }^{27}$ but there is a long way yet to go.

${ }^{27}$ See Goodhart, Surinand, and Tsomocos, 2004 and 2005; and Goodhart, Zicchino, and Tsomocos, 2005). 
Appendix 1. Impulse Responses of Credit to Asset Prices Shocks and Asset Prices to Credit Shocks

\begin{tabular}{|c|c|c|c|c|}
\hline \multicolumn{5}{|c|}{ Figure A1. Dynamic Interaction Between Credit and Asset Prices } \\
\hline & $\begin{array}{l}\text { Credit to Aggregate Asset } \\
\text { Prices }\end{array}$ & Credit to house prices & $\begin{array}{l}\text { Aggregate asset prices } \\
\text { to credit }\end{array}$ & House prices to credit \\
\hline 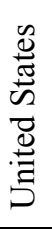 & 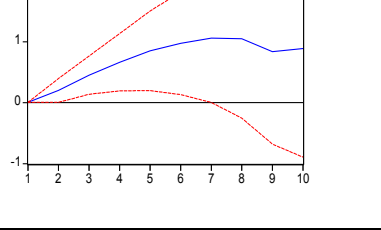 & 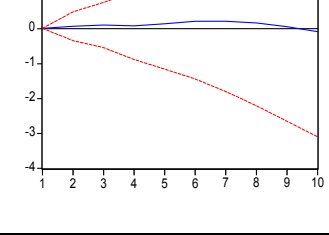 & (1) & 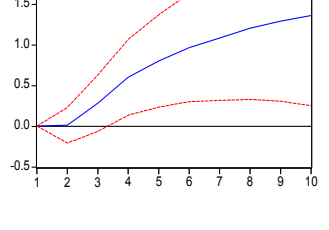 \\
\hline 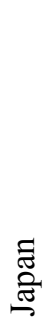 & 我地, & 10. & L & 我 \\
\hline 空 & |lis & (2) & 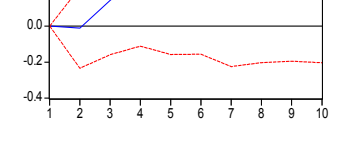 & |l \\
\hline 总 & (12) & (12) & (1) & 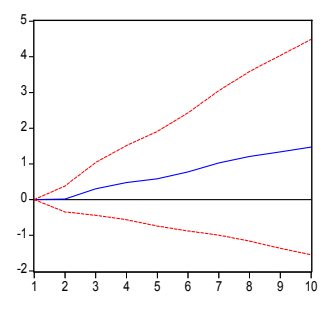 \\
\hline 齐 & 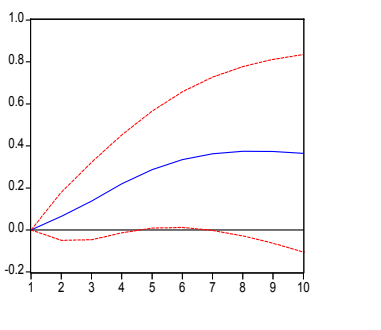 & 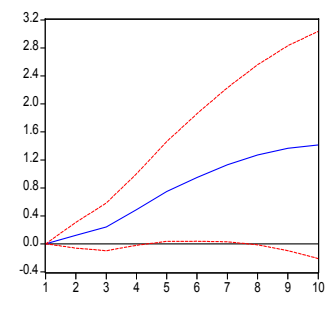 & 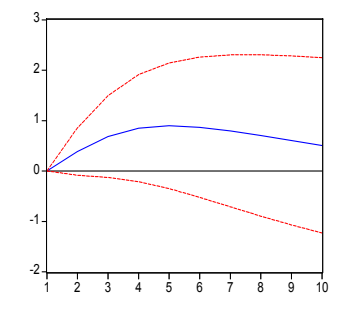 & (15) \\
\hline
\end{tabular}




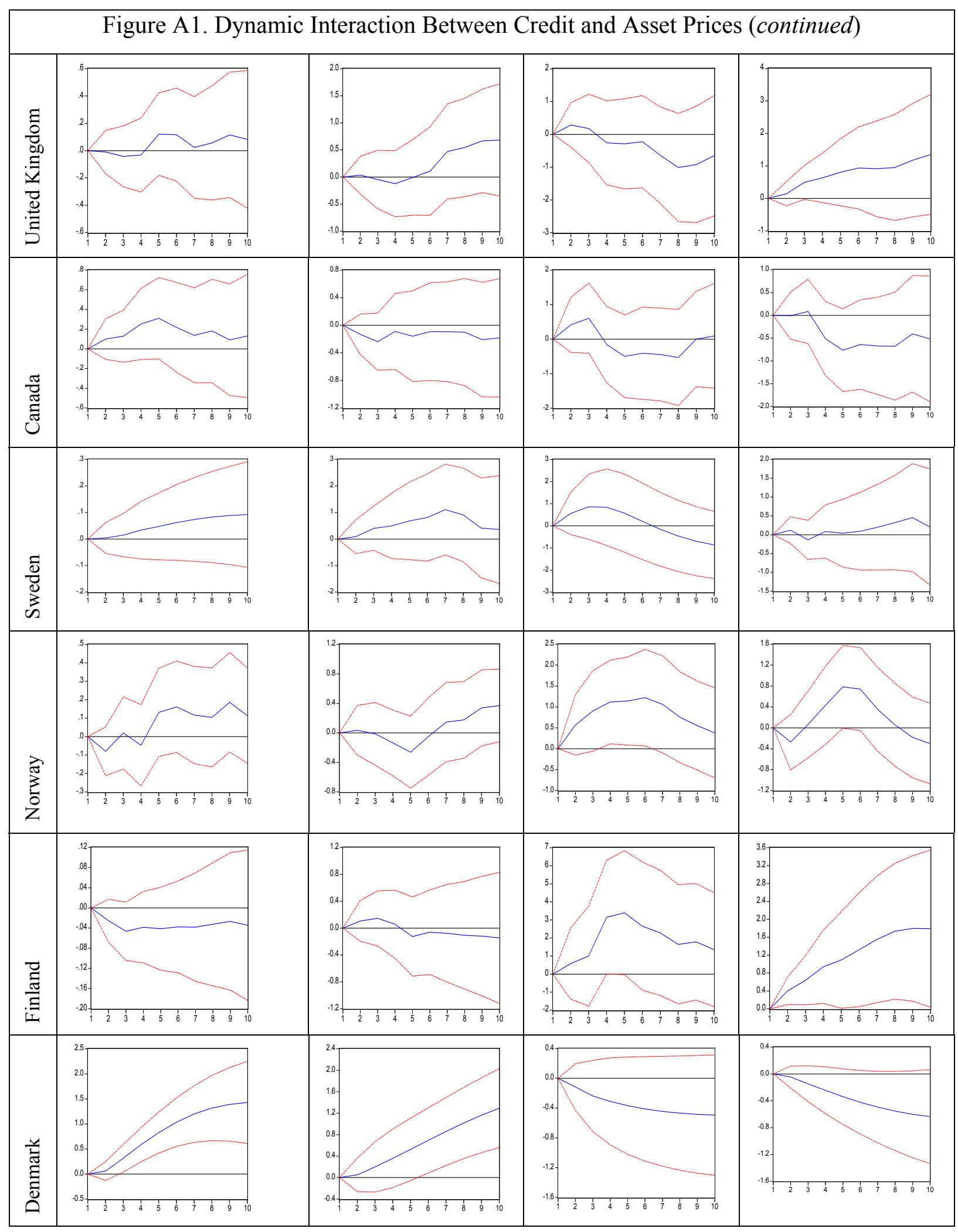




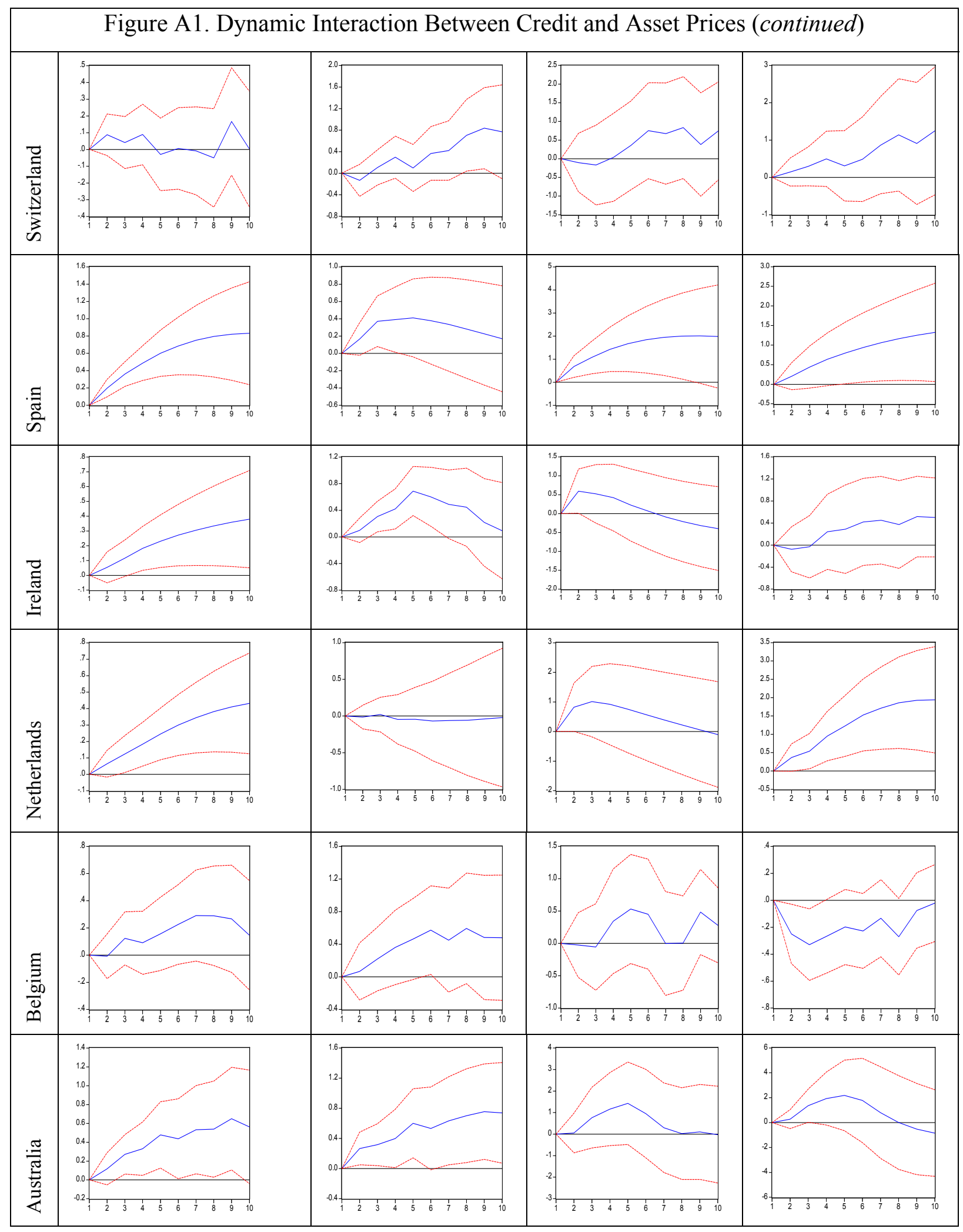




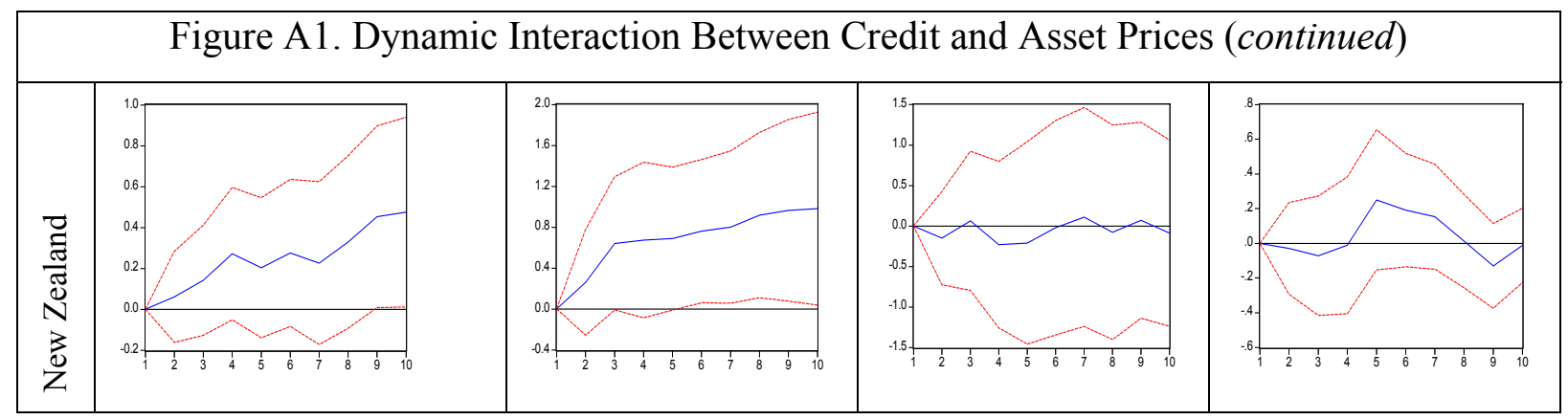

Note: The figures display impulse responses to a one nonfactorized one unit shock in a two standard error confidence band. 
Appendix 2. Correlation Structures

The correlation structures of the dependent variable and real investment or investment over GDP, asset prices, and credit over GDP are presented in the following matrices.

\begin{tabular}{|l|c|c|c|c|c|}
\hline \multicolumn{7}{|c|}{} & $\mathrm{T} 4$ & $\mathrm{~T} 8$ & $\mathrm{~T} 12$ & $\mathrm{~T} 24$ & $\mathrm{~T} 28$ \\
\hline Argentina & 0.2938 & -0.1720 & -0.2362 & 0.0107 & 0.2160 \\
\hline Canada & 0.0047 & -0.4407 & -0.3732 & -0.3300 & -0.2448 \\
\hline Denmark & 0.1016 & 0.0639 & 0.3008 & -0.0617 & 0.0269 \\
\hline Finland & -0.0045 & -0.0322 & -0.0493 & -0.0843 & -0.0319 \\
\hline France & -0.0414 & 0.1206 & 0.0339 & -0.0646 & 0.0918 \\
\hline Germany & 0.3671 & 0.1864 & -0.0361 & 0.0961 & 0.2777 \\
\hline Italy & -0.0910 & 0.1979 & 0.3469 & -0.2529 & -0.1955 \\
\hline Japan & 0.3492 & 0.1044 & 0.0172 & -0.5189 & 0.0268 \\
\hline Korea & -0.0144 & -0.0826 & -0.1066 & 0.0494 & 0.1198 \\
\hline Mexico & 0.0439 & -0.6898 & -0.1532 & 0.5141 & $\mathrm{~N} / \mathrm{A}$ \\
\hline Netherlands & 0.0321 & -0.1119 & -0.3317 & 0.2460 & 0.2625 \\
\hline Norway & 0.1031 & -0.0002 & -0.1853 & -0.1882 & -0.2857 \\
\hline Spain & 0.1206 & 0.4360 & 0.5539 & -0.4202 & $\mathrm{~N} / \mathrm{A}$ \\
\hline Sweden & 0.0465 & 0.2962 & 0.4213 & -0.1139 & -0.1107 \\
\hline Thailand & 0.1262 & -0.1026 & -0.1264 & -0.1814 & -0.2961 \\
\hline United Kingdom & 0.1616 & 0.5424 & 0.3985 & -0.4340 & -0.3505 \\
\hline United States & 0.2721 & 0.2825 & 0.1994 & -0.2369 & -0.6638 \\
\hline
\end{tabular}

\begin{tabular}{|c|c|c|c|c|c|c|}
\hline & $\mathrm{T} 4$ & T8 & $\mathrm{T} 12$ & $\mathrm{~T} 16$ & $\mathrm{~T} 20$ & $\mathrm{~T} 24$ \\
\hline \multicolumn{7}{|c|}{ CORRY(Y,GapAGGASPRI) } \\
\hline Argentina & -0.1173 & 0.1423 & 0.3196 & 0.0764 & 0.2205 & 0.1447 \\
\hline Canada & 0.3561 & 0.2034 & -0.2112 & -0.2721 & 0.2365 & -0.2894 \\
\hline Denmark & 0.3421 & 0.3985 & 0.1231 & -0.2244 & -0.4301 & -0.5868 \\
\hline Finland & -0.0048 & -0.1747 & -0.1627 & -0.1297 & 0.4133 & 0.2523 \\
\hline France & 0.2188 & 0.1170 & 0.0179 & -0.0185 & 0.0770 & -0.2690 \\
\hline Germany & 0.1580 & 0.1931 & 0.1728 & 0.1355 & -0.3037 & -0.6535 \\
\hline Italy & 0.4348 & 0.4751 & 0.2352 & 0.0052 & -0.2544 & -0.4447 \\
\hline Japan & 0.3974 & 0.1266 & -0.1758 & -0.3984 & -0.2483 & -0.2024 \\
\hline Korea & -0.1224 & -0.0985 & -0.1394 & -0.0065 & 0.1349 & 0.1540 \\
\hline Mexico & 0.0605 & -0.3207 & -0.3641 & 0.1131 & 0.5302 & 0.3729 \\
\hline Netherlands & 0.1332 & 0.2585 & 0.2812 & 0.1024 & -0.3301 & -0.6754 \\
\hline
\end{tabular}




\begin{tabular}{|l|c|c|c|c|c|c|c|}
\hline & $\mathrm{T} 4$ & $\mathrm{~T} 8$ & $\mathrm{~T} 12$ & $\mathrm{~T} 16$ & \multicolumn{2}{c|}{$\mathrm{T} 20$} & $\mathrm{~T} 24$ \\
\hline \multicolumn{7}{|c|}{ CORRY(Y,GapAGGASPRI $)$} \\
\hline Norway & 0.3179 & 0.3197 & -0.0347 & 0.0570 & 0.4074 & -0.3000 \\
\hline Spain & 0.3393 & 0.7753 & 0.6943 & 0.2350 & -0.4350 & -0.8048 \\
\hline Sweden & 0.4013 & 0.2589 & 0.1655 & 0.1145 & -0.0081 & -0.1730 \\
\hline Thailand & -0.2777 & 0.0038 & 0.5195 & 0.0143 & -0.0786 & 0.0995 \\
\hline United Kingdom & 0.2411 & 0.5118 & 0.3713 & -0.0729 & -0.1264 & -0.6082 \\
\hline United States & 0.4231 & 0.4806 & 0.2309 & -0.1399 & -0.4365 & -0.5337 \\
\hline & & \multicolumn{7}{|l|}{} & \\
\hline Argentina & 0.1760 & 0.2037 & 0.0990 & 0.0007 & -0.0215 & -0.3854 \\
\hline Canada & -0.1020 & 0.2191 & 0.1279 & 0.0551 & -0.2381 & -0.1623 \\
\hline Denmark & 0.3327 & 0.5197 & -0.0091 & -0.4758 & -0.2916 & -0.0147 \\
\hline Finland & -0.1964 & 0.1937 & 0.3128 & 0.3486 & 0.2491 & 0.1145 \\
\hline France & 0.0996 & 0.1726 & 0.1118 & -0.1715 & -0.0783 & 0.1412 \\
\hline Germany & -0.1220 & 0.0367 & 0.1335 & 0.4153 & 0.2706 & 0.0088 \\
\hline Italy & 0.4318 & 0.3523 & 0.0147 & -0.4482 & -0.5322 & -0.0816 \\
\hline Japan & -0.0181 & 0.0638 & 0.1017 & -0.3682 & -0.4526 & -0.1924 \\
\hline Korea & -0.0604 & -0.0639 & -0.2285 & -0.1992 & -0.2193 & 0.1626 \\
\hline Mexico & -0.6030 & -0.3000 & 0.5733 & 0.1110 & 0.0063 & 0.0787 \\
\hline Netherlands & 0.2706 & 0.4137 & 0.1197 & -0.2471 & -0.3107 & -0.0548 \\
\hline Norway & -0.1259 & -0.0721 & 0.2517 & 0.6240 & 0.1730 & -0.0841 \\
\hline Spain & 0.2729 & 0.6531 & -0.2434 & -0.4405 & -0.2853 & -0.3978 \\
\hline Sweden & 0.0315 & 0.4094 & 0.2381 & -0.0433 & -0.0829 & -0.0654 \\
\hline Thailand & 0.0898 & 0.5137 & 0.1989 & -0.3549 & -0.4271 & -0.1631 \\
\hline United Kingdom & 0.3946 & 0.5688 & 0.0425 & -0.3692 & -0.2023 & -0.3571 \\
\hline United States & 0.1941 & 0.2883 & 0.2755 & 0.1353 & -0.3419 & -0.4367 \\
\hline
\end{tabular}

Source: Authors' calculations. 


\section{References}

Allen, F., and D. Gale, 1998, "Bubbles and Crises," The Economic Journal, Vol. 110, No. 460 .

, 1999, "Bubbles, Crises, and Policy," Oxford Review of Economic Policy, Vol. 15, No. 3, pp. 9-18.

Altman, E., A. Elizondo, and Miguel Segoviano, 2002, "Medicion Integral del Riesgo de Credito," (unpublished).

Ando, A. and F. Modigliani, 1963, "The 'Life Cycle' Hypothesis of Saving: Aggregate Implications and Tests," American Economic Review, Vol. 53, pp. 55-84.

Arkelof, G., and P. Romer, 1993, "Looting: The Economic Underworld of Bankruptcy for Profit," Brookings Papers on Economic Activity, Vol. 2, Brookings Institution, pp. 173.

Basel Committee on Banking Supervision, 1988, "International Convergence of Capital Measurement and Capital Standards," Basel, (July).

Berger, A., and G. Udell, 1990, “Collateral, Loan Quality, and Bank Risk," Journal of Monetary Economics, Vol. 25, No.1, pp. 21-42.

_ 2003, "The Institutional Memory Hypothesis and the Procyclicality of Bank Lending Behavior,” BIS Working Paper 125 (Basel: Bank for International Settlements).

Bernanke, B., and M. Gertler, 1989, "Agency Costs, Collateral, and Business Fluctuations," American Economic Review, Vol. 79, pp. 14-31.

, and S. Gilchrist, 1998, “The Financial Accelerator in a Quantitative Business Cycle Framework," NBER Working Paper No. 6455 (Cambridge, MA: National Bureau of Economic Research).

and S. Gilchrist, 1999, "The Financial Accelerator in a Quantitative Business Cycle Framework," Handbook of Macroeconomics, Vol. 1C, edited by J.B. Taylor and M. Woodford, pp. 1341-93.

Black, F., and M. Scholes, 1973, “The Pricing of Options and Corporate Liabilities," Journal of Political Economy, Vol. 81, No.3, 637-59.

Bank for International Settlements, 1999, "The Monetary and Regulatory Implications of Changes in the Banking Industry," Bank for International Settlements Conference Papers No.7. 
— 2001, 71 Annual Report (Basel: Bank for International Settlements).

Borio, C., and W. Fritz, 1995, "The Response of Short-Term Bank Lending Rates to Policy Rates: A Cross-Country Perspective," BIS Working Paper No. 27 (Basel: Bank for International Settlements).

— N. Kennedy, and S. Prowse, 1994, "Exploring Aggregate Asset Price Fluctuations Across Countries: Measurement, Determinants and Monetary Policy Implications," BIS Economic Paper 40 (Basel: Bank for International Settlements).

— and P. Lowe, 2002, "Asset Prices, Financial and Monetary Stability: Exploring the Nexus,” BIS Working Paper 114 (Basel: Bank for International Settlements).

Calvo, G., 1998, "Varieties of Capital-Market Crises," in The Debt Burden and its Consequences for Monetary Policy, edited by G. Calvo and M. King, (New York: McMillan Press).

- L. Leiderman, and C. Reinhart, 1993, "Capital Inflows and Real Exchange Rate Appreciation: The Role of External Factors," Staff Papers, International Monetary Fund, Vol. 40 No.1, pp. 108-51.

_ and E. Mendoza, 1996, "Petty Crime and Cruel Punishment: Lessons From the Mexican Debacle," American Economic Review, Vol. 86 No. 2, pp. 170-75.

Deaton, A., 1992, Understanding Consumption, (Oxford: Oxford University Press).

Demirgüc-Kunt, A., and E. Detriagiache, 1998, "The Determinants of Banking Crises: Evidence from Developing and Developed Countries," Staff Papers, International Monetary Fund, Vol. 45, No. 1.

— 1999, "Financial Liberalization and Financial Fragility," in Proceedings of the World Bank Annual Conference on Development Economics, edited by B. Pleskovic and J. Stiglitz (Washington: World Bank).

— , 2005, "Cross-Country Empirical Evidence of Systemic Banking Distress: A Survey," IMF Working Paper 05/96 (Washington: International Monetary Fund).

Dooley, M., 1997, “A Model of Crises in Emerging Markets,” NBER, Working Paper 6300 (Camridge, MA: National Bureau of Economic Research).

Drees, B., and C. Pazarbasioglu, 1998, "The Nordic Banking Crises: Pitfalls in Financial Liberalization?" IMF Occasional Paper No. 161 (Washington: International Monetary Fund).

Eichengreen, B., and C. Areta, 2000, "Banking Crises in Emerging Markets: Presumptions 
and Evidence," CIDER Paper, C00-115 9 (Berkeley: Center for International and Development Economics Research).

and M. Bordo, 2003, "Crises Now and Then: What Lessons From the Last Era of Financial Globalization,", in Monetary History, Exchange Rates, and Financial Markets; Essays in honor of Charles Goodhart, Vol. 2, edited by P. Mizen (Cheltenham: Edward Elgar).

Fisher, I., 1933, “The Debt-Deflation Theory of Great Depressions," Econometrica, Vol. 1, pp. 337-57.

Flood, R., and N. Marion, 1999, "Perspectives on the Recent Currency Crisis Literature," International Journal of Finance and Economics, Vol. 4, No. 1, pp. 1-26.

Frankel, J., and A. Rose, 1996, "Currency Crashes in Emerging Markets: An Empirical Treatment," Journal of International Economics, Vol. 41 (Nos. 3-4, pp. 351-66.

Galbis, V., 1993, "High Real Interest Rates Under Financial Liberalization: Is There a Problem?” IMF Working Paper 93/7 (Washington: International Monetary Fund).

Garber, P., and S. Lall, 1996, "Derivative Products in Exchange Rate Crises” (unpublished).

Gerlach, S., and W. Peng, 2003, "Bank Lending and Property Prices in Hong Kong," HKIMR Working Paper No. 12/2003 (Hong Kong: Hong Kong Institute for Monetary Research).

Goldstein, M., G. Kaminsky, and C. Reinhart, 2000, Assessing Financial Vulnerability: An Early Warning System for Emerging Markets, (Washington: Institute for International Economics).

Goodhart, Charles ,1995, "Price Stability and Financial Fragility," in Financial Stability in a Changing Environment, edited by K. Sawamoto, Z. Nakajima, and H. Taguchi (New York: St. Martin's Press).

—, and Boris Hofmann, 2003, "Deflation, Credit, and Asset Prices," in The Anatomy of Deflation by P. Siklos and R. Burdekin (Cambridge, UK: Cambridge University Press.

_- Boris Hofmann, and Miguel Segoviano, 2004, "Bank Regulation and Macroeconomic Fluctuations," Oxford Review of Economic Policy, Vol. 20, No. 4, pp. 591-615. , and Miguel Segoviano, 2004, "Basel and Procyclicality: A Comparison of the Standardized and IRB Approaches to an Improved Credit Risk Method," London School of Economics, Financial Markets Group, Discussion Paper 524. 
, P. Sunirand, and D. Tsomocos, 2004a, "A Model to Analyze Financial Fragility: Applications," Journal of Financial Stability, Vol. 1, pp. 1-30.

— Fragility in the U.K. Banking System," Oxford Financial Research Centre, Working Paper 2004-FE-18.

P. Sunirand, and D. Tsomocos, 2005, "A Risk Assessment Model for Banks," Annals of Finance Vol. 1, No. 2, pp. 197-224.

Goodhart, C., Sunirand, P., Tsomocos, D., 2006, "A Model to Analyze Financial Fragility," Economic Theory 27, No. 1, pp107-142.

Hodrick, R., and E. Prescott, 1980, "Post-War U.S. Business Cycles: An Empirical Investigation," Carnegie-Mellon University, Discussion Paper 451.

Hofmann, B., 2001, “The Determinants of Private Sector Credit in Industrialized Countries: Do Property Prices Matter?” BIS Working Paper No. 108 (Basel: Bank for International Settlements).

— Societies’ Retail Rates,” Bank of England Working Paper No. 117.

Hoshi, T., and A. Kashyap, 1999, “The Japanese Banking Crisis: Where Did it Come From and How Will it End?" NBER Working Paper No. 7250 (Cambridge, MA: National Bureau of Economic Research).

International Monetary Fund, 2000, World Economic Outlook, May 2000 (Washington: International Monetary Fund).

— , 2003, Global Financial Stability Report, September2003 (Washington: International Monetary Fund).

Jaynes, E., 1957, “Information Theory and Statistical Mechanics," Physical Review Vol. 106, No. 2, pp. 620-30.

Judge, G., and A. Golan, 1992, "Recovering Information in the Case of Ill-Posed Inverse Problems with Noise,” Working Paper, University of California Berkeley.

Kaminsky, G., S. Lizondo, and C. Reinhart, 1998, "Leading Indicators of Currency Crises," Staff Papers, International Monetary Fund, Vol. 5 No. 1, pp. 1-48.

and C. Reinhart, 1996, "Banking and Balance of Payments Crises: Models and Evidence," Board of Governors of the Federal Reserve Working Paper (Washington: Board of Governor of the Federal Reserve). 
, and C. Reinhart, 1999, "The Twin Crisis: The Causes of Banking and Balance of Payments Problems," American Economic Review, Vol. 89, No.3, pp. 473-500.

, and S. Schmukler, 2003, "Short-Run Pain, Long-Run Gain: The Effects of Financial Liberalization,” NBER Working Paper 9787 (Cambridge, MA: National Bureau of Economic Research).

Keynes, J., 1931, “The Consequences for the Banks of the Collapse in Money Values" in Essays in Persuasion, ed. by J. Keynes (New York: MacMillan).

Khamis, May, 1996, "Credit and Exchange Rate-Based Stabilization," IMF Working Paper 96/51 (Washington: International Monetary Fund).

Kindleberger, C., 1978, "Manias, Panics, and Crashes: A History of Financial Crises," in Financial Crises: Theory, History and Policy, edited by C. Kindleberger and J. Laffarge (London: Cambridge University Press).

Kiyotaki, N., and J. Moore, 1997, “Credit Cycles,” Journal of Political Economy, Vol. 105, No. 2, pp. 211-48.

Krugman, P., 1979, “A Model of Balance of Payments Crises," Journal of Money, Credit, and Banking, Vol. 2, No. 3, pp. 311-25.

Knight, M., and J. Santaella, 1997, "Economic Determinants of IMF Financial Arrangements," Journal of Development Economics, Vol. 54, No. 2, pp. 405-36.

McKinnon, R., and H. Pill, 1996, "Credible Liberalizations and International Capital Flows: The Over Borrowing Syndrome," in Financial Deregulation and Integration in East Asia, edited by T. Ito and A. Krueger, pp. 7-45 (Chicago: University of Chicago Press).

Merton, R., 1974, "On the Pricing of Corporate Debt: The Risk Structure of Interest Rates," The Journal of Finance, Vol. 29, No. 2, pp. 449-70.

Minsky, H., 1982, “Can It Happen Again?” Essays on Instability and Finance (Arononk, N.Y. M.E. Sharpe).

Mishkin, F., 1997, "Understanding Financial Crises: A Developing Country Perspective," in Annual World Bank Conference on Development Economics 1996, edited by Michael Bruno and Boris Pleskovic (Washington: World Bank).

Mishra, D., 1997, "Political Determinants of Currency Crises: Theory and Evidence," University of Maryland (unpublished).

Muellbauer, J., 1994, "The Assessment: Consumer Expenditure," Oxford Review of Economic Policy, Vol. 10, No. 2, pp. 1-41. 
Obstfeld, M., 1995, “Models of Currency Crises with Self-Fulfilling Features," NBER Working Paper 5285 (Cambridge, MA: National Bureau of Economic Research).

— Paper 5191 (Cambridge, Massachusetts: MIT Press).

Organization for Economic Cooperation and Development, 2000, Economic Outlook 68 (Paris, OECD).

Pukelsheim, F., 1994, “The Three Sigma Rule,” American Statistician, Vol. 48 No.4, pp. $88-91$.

Pill, H., and M. Pradhan, 1995, "Financial Indicators and Financial Change in Africa and Asia," IMF Working Paper 95/123 (Washington: International Monetary Fund).

Segoviano, Miguel, and P. Lowe, 2002, "Internal Ratings, the Business Cycle and Capital Requirements: Some Evidence from an Emerging Market Economy," BIS Working Paper 117, (Basel: Bank for International Settlements).

— 2004, "A System for Measuring Credit Risk When Only Limited Data is Available," Credit Risk International, London (October).

— , 2006, “The Conditional Probability of Default Methodology”, Financial Markets Group, London School of Economics, Discussion Paper 558.

Shapley, L., and Martin Shubik, 1977, “Trading Using one Commodity as a Means of Payment," Journal of Political Economy, Vol. 85 No.5, pp. 937-68.

Shubik, Martin, 1973, “Commodity Money, Oligopoly, Credit, and Bankruptcy in a General Equilibrium Model,” Western Economic Journal Vol. 10, No. 4, pp. 24-38.

-1999, The Theory of Money and Financial Institutions (Cambridge, MA: MIT Press). , and D. Tsomocos, 1992, “A Strategic Market Game with a Mutual Bank with Fractional Reserves and Redemption in Gold," Journal of Economics, Vol. 55 No. 2, pp. 123-50.

Sturm, J., H. Berger, and J. Haan, 2004, "Which Variables Explain Decisions on IMF Credit?: An Extreme Bounds Analysis," University of Groningen, Faculty of Economics.

Vassalou, M., and Y. Xing, 2002, “Default Risk in Equity Returns,” Columbia University Working Paper.

Vreeland, J., 1999, “The IMF: Lender of Last Resort or Scapegoat”? Yale University, Department of Political Science, Leitner Working Paper 1999-03. 